\title{
Distal radius kırıklarına genel bakış ve konservatif tedavisi
}

\section{Overview and conservative treatment of distal radius fractures}

\author{
Eftal Güdemez ${ }^{1,2}$, Serkan Uludağ $\breve{3}^{3}$, Yaprak Ataker ${ }^{4}$ \\ ${ }^{1}$ Koç Üniversitesi Tıp Fakültesi, Ortopedi ve Travmatoloji Bölümü, Rumeli Feneri, İstanbul \\ ${ }^{2}$ Amerikan Hastanesi Ortopedi ve Travmatoloji Bölümü, El ve Mikrocerrahi Ünitesi, Nişantaşı, İstanbul \\ ${ }^{3}$ Amerikan Hastanesi, Ortopedi ve Travmatoloji Bölümü, Nişantaşı, İstanbul \\ ${ }^{4}$ Amerikan Hastanesi, Fizik Tedavi ve Rehabilitasyon Bölümü, Nişantaşı, İstanbul
}

\begin{abstract}
Distal radius kırıkları genellikle el açık vaziyette yere düşme ile oluşur. Metafiz bölümünde oluşan basit tarzdaki kırıklardan, eklem içine ulaşan parçalı, karmaşık ve zor kırıklara kadar olan geniş bir yelpaze gösterir. Distal radius kırığı tedavisinin amaçları: 1) hastaya ağrısız ve yeterli bir el bileği hareketi kazandırmak, 2) hastayı travma öncesi aktivitesine döndürmek ve 3 ) hastada erken ve uzun vadede dejeneratif değişiklik ve sekel riskini azaltmaktır. Konservatif tedavi, kendine göre zorlukları olan zahmetli bir yöntemdir; sık radyolojik ve klinik takip gerektirir; basit değildir, derin bilgi birikimi ve deneyim gerektirir ve komplikasyonların nadir olmadığı bir tedavi şeklidir. Bu derlemede, distal radius kırığının konservatif yöntemlerle tedavi edilme şartları, endikasyonları, kontrendikasyonları ve bir hastanın baştan sona kadar yaşadığı sürecin ayrıntıları ele alınacak; standart protokoller, olası problemler ve komplikasyonlar durumunda yapılacak tıbbi tedavi ve rehabilitasyon alternatifleri anlatılacaktır.
\end{abstract}

Anahtar sözcükler: distal radius kırıkları; konservatif tedavi; komplikasyonlar
The most common mechanism of the distal radius fractures is falling down with the hand outstretched. These fractures show a great variety: ranging from a simple metaphyseal bending to intra-articular, comminuted, and unstable complex type of fractures. The purposes of the treatment are; 1 ) to provide an acceptable and painless range of motion to the patient's wrist, 2) to bring back the patient to the preinjury daily activity level, and 3 ) to reduce the risk of degenerative changes and possible permanent disability. Conservative treatment is more cumbersome with particular difficulties; it requires frequent radiographic and clinical control; it is not a simple treatment modality and demands deep knowledge and experience; its complications are not rare. This review will cover the prerequisites, indications, and contraindications of conservative treatment of the distal radius. The process of treatment will be explained from beginning to the end with recommended standard protocols; alternative solutions and treatment procedures will be given for the potential complications and problems.

Key words: distal radius fractures; conservative treatment; complications

Distal radius kırığı oluşan bir hastanın tüm tedavi süreci, kırık iyileşmesinin biyolojisi, doku iyileşmesi ve kırık tespitinin biyomekaniği üzerine planlanır. Kırığın şekline ve hastaya özel durumlara göre tedavi ve rehabilitasyon protokolü çizilir. Kırığın sadece kemiği etkilemediğinin farkında olmak gerekir. Watson-Jones'un yıllar önce söylediği "Kırık, kemiği de içine alan bir yumuşak doku travmasıdır" kavramı halen geçerlidir. Kırığı çevreleyen yumuşak doku kılıfı fonksiyonel sonucu büyük ölçüde etkiler. Ödem, ağrı ve eklem sertliği ile sonuçlanacak inflamasyon süreci, kırık iyileşmesi devam ederken, çok iyi bir şekilde tedavi edilmelidir. ${ }^{[3,4]} \mathrm{Bu}$ derleme, distal radius kırığının konservatif yöntemlerle tedavi edilme

- Illetişim adresi: Prof. Dr. Eftal Güdemez. Koç Üniversitesi Tıp Fakültesi. Ortopedi ve Travmatoloji Bölümü. Rumeli Feneri Yolu, 34450, Sarıyer, İstanbul. Tel: 0212 - 3881000 Faks: 0212 -3881168 e-posta: egudemez@ku.edu.tr eftalg@amerikanhastanesi.org

- Geliș tarihi: 25 Șubat 2014 Kabul tarihi: 25 Șubat 2014 
şartlarının, endikasyonlarının, kontrendikasyonlarının ve bir hastanın baştan sona kadar yaşadığı sürecin ayrıntılarının ile ele alınacağı; standart protokoller, olası problemler ve komplikasyonlar durumunda yapılacak tıbbi tedavi ve rehabilitasyon alternatiflerinin anlatılacağı bir yazıdır.

\section{GENEL DEĞERLENDIRME}

\section{Sınıflandırma}

Görüntülemedeki gelişmeler ve teknolojik ilerlemeler kırıktaki kaymaların miktarının, yönünün ve derecesinin belirlenmesinde, eklemi ilgilendiren veya eklem dışı kırıkların tetkikinde yardımcı olmuştur. Kırığın bu şekilde ayrıntılı incelenmesi, farklı sınıflandırma sistemlerinin oluşmasını sağlamıştır. Ama bu sınıflamaların hem güvenilir olacak kadar fonksiyonel hem de tedaviyi yönlendirecek ve elde edilecek sonuçlar hakkında öngörüye yardımcı olacak kadar kullanışlı olması gerekir. Bununla birlikte günümüzde hiçbir sınıflama sistemi bu tanımı tam anlamıyla karşılamamaktadır. ${ }^{[1]}$

Literatürde tanımlanmış bir çok sınıflandırma vardır; burada en çok kullanılanlardan bahsedilecektir. Melone sınıflandırması distal radiusu dört ana parçaya ayırarak değerlendirir: 1) cisim, 2) radyal stiloid, 3 ) dorsal mediyal parça ve 4) volar mediyal parça. Cerrahi tedaviyi tanımlayan ve endikasyonları belirleyen yaygın bir sınıflandırma olmasına rağmen standart röntgen görüntülerine göre kullanılmasının doğruluğu ve güvenilirliği tartışmalıdır (Şekil 1). ${ }^{[1,2]}$
AO/ASIF sınıflandırması 1987'de yayımlanmıştır. Eklem dışı, kısmen eklemi ilgilendiren ve eklem içi olacak şekilde üç ana gruba ve 27 alt tipe ayrılır; yüksek güvenilirliği olan bir sınıflandırmadır (Şekil 2). ${ }^{[1,2]}$

Fernandez, kırığın oluş mekanizmasına göre bir sınıflandırma tanımlamıştır. Bu sınıflandırmanın, pratik olması ve tedaviyi yönlendirmesi gibi avantajları vardır; stabil olup olmama, beraberinde başka yaralanmaların varlığı, pediatrik karşıııları gibi değişkenler değerlendirilebilmektedir (Şekil 3). ${ }^{[1,2]}$

\section{Epidemiyoloji}

Distal radius kırıklarının gerçek görülme oranları, kırık tiplerine ve çeşitlerine göre görülme sıklıkları veya tedavi istatistikleri hakkında doğru epidemiyolojik rakamlar vermek genellikle zordur. ${ }^{[1,5]}$ Bununla birlikte, geniş bir derleme çalışmada, tüm distal radius kırıklarının \%48'inin eklem dışı kırıklar olduğu, kalan eklem içi kırıklarının ise \%10'unun kısmen eklemi ilgilendirdiği, \%42'sinin ise tamamen eklem içi olduğu bildirilmiştir. ${ }^{[5]}$ Eklem dışı kırıkların içinde \%15'lik bir kısmın çok az kayma gösterdiği görülmüş ve bu kırıkların esas konservatif tedavi edilen hastalar olduğu sonucuna varılmıştır. Eklem dışı kırıkların çoğunluğunun, \%26 oranla, konservatif tedaviye uygun olmayan dorsal metafizyel parçalanma gösteren kırıklar olduğu fark edilmiştir.

\section{Tedavi planı ve uygulama}

Düşme şikayeti ile gelen hastanın muayenesi ve ardından radyolojik incelemesi yapıldıktan sonra, distal

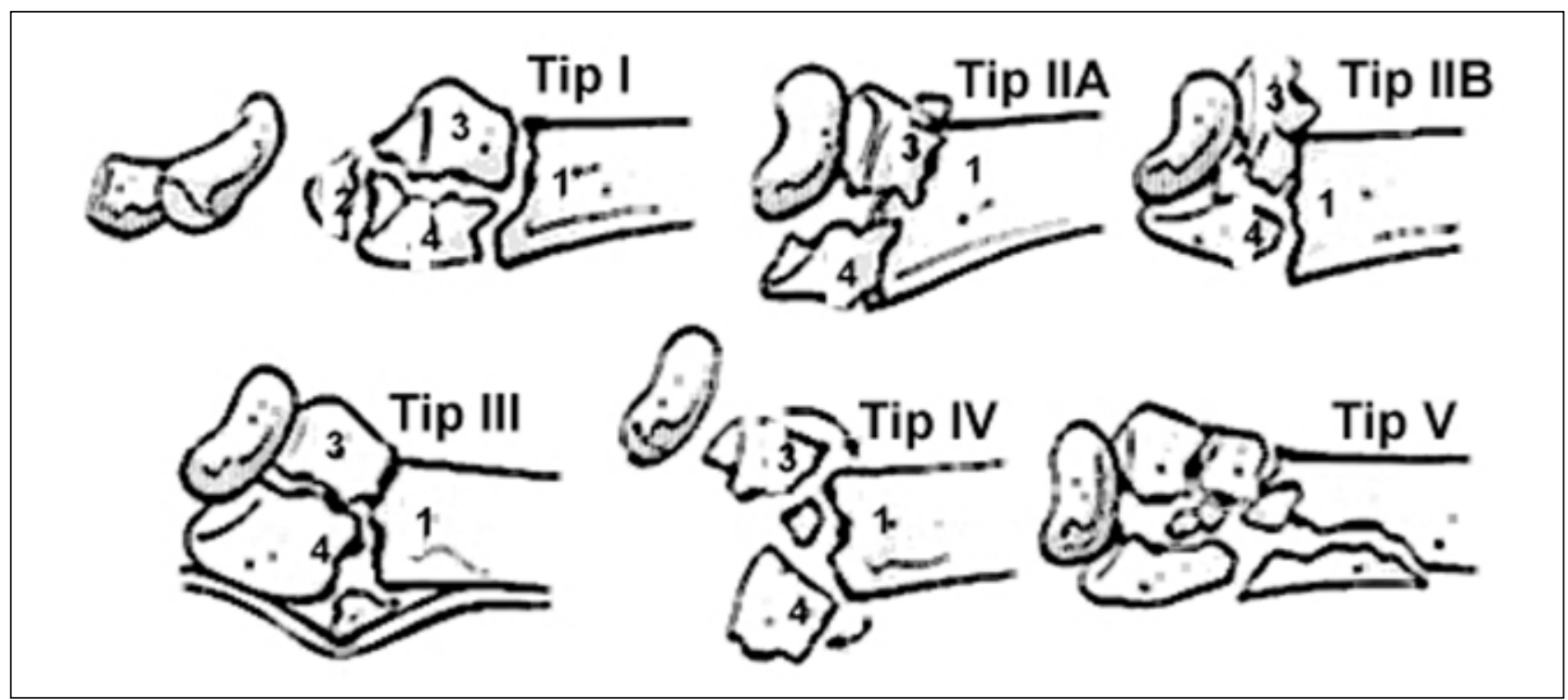

Şekil 1. Melone sınıflandırması (Melone CP Jr. Articular fractures of the distal radius. Orthop Clin North Am 1984;15(2):217-36.'dan esinlenerek yeniden yapılmıştır). 


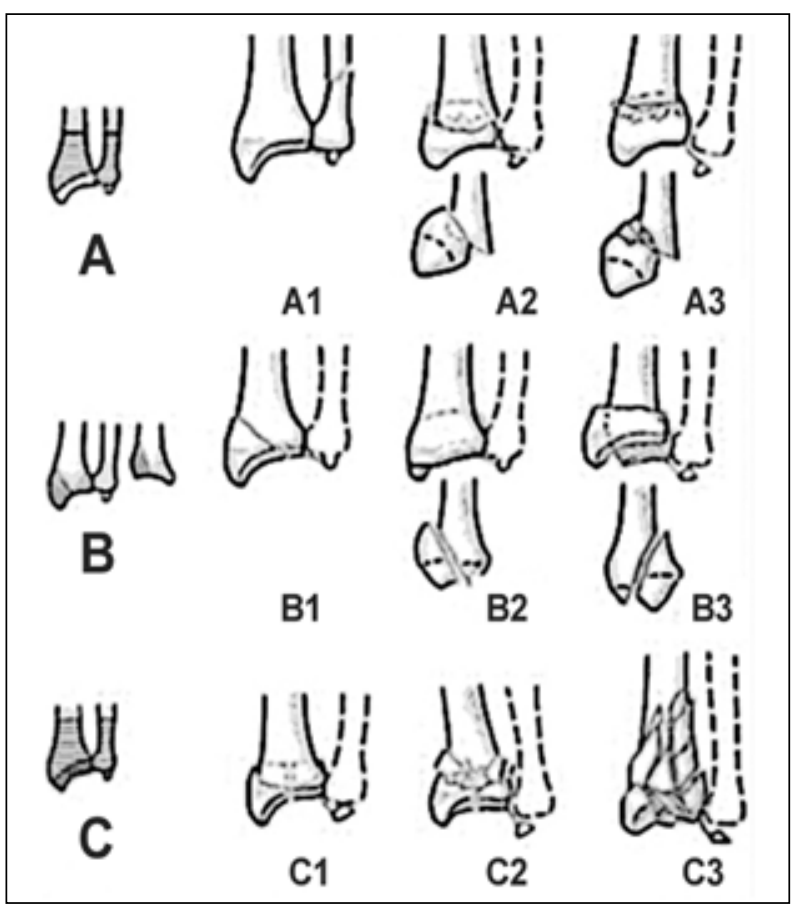

Şekil 2. AO/ASIF sınıflandırması (Muller ME, Nazarian $S$, Koch P, Schatzker J. The Comprehensive Classification of Fractures of Long Bones. Berlin, Germany: Springer-Verlag; 1990.'dan esinlenerek yeniden yapılmıştır. Cross Ref)

radius kırığı tanısı alıyorsa, bir sonraki aşama doğru tedavinin planlanmasıdır. Distal radius kırığı tedavisinin amaçları, hastaya ağrısız yeterli bir el bileği hareketi kazandırmak, onu travma öncesi aktivitesine döndürmek, erken ve uzun vadede dejeneratif değişiklik ve sekel riskini azaltmaktır. Tedavi yöntemini belirleyen etmenler; hastanın yaşı, kemik kalitesi, mesleği, genel sağlık durumu, kırığın şekli, birlikte görülen lezyonlar ve tedaviyi yapan kişinin deneyimidir. Bu kırıkların yıllar içinde daha iyi anlaşılması, el bileği biyomekaniğinin irdelenmesi ve günümüzdeki teknolojik gelişmeler, tedavinin evrimleşmesine neden olmuştur. ${ }^{[5-7]}$

Son yıllarda gelişen ve çok iyi sonuçlar alınan cerrahi tedavi seçenekleri olmasına rağmen, bazı kırıklar için kapalı redüksiyon ve alçı ile tespit seçeneği halen geçerlidir. Konservatif tedavi, kendine göre zorlukları olan zahmetli bir yöntemdir. Sık radyolojik ve klinik takip gerektirir. Redüksiyonun takibi ve ikincil kaymaların önlenmesi için sık alçı değişimleri gerekebilir. Bununla beraber, hangi kırığa konservatif tedavinin uygulanacağı kararını vermede göz önünde bulundurulması gereken esas ölçüt, kapalı redüksiyon sonrası kırığın redükte olabilmesi ve stabil kalabilmesidir (alçı içinde tekrar kaymamasıdır). Bu tedavinin amacı, kırığın anatomik düzgünlüğünün sağlanması ve kemik iyileşmesinin olgunlaşacağı 4-6. hafta sonuna kadar
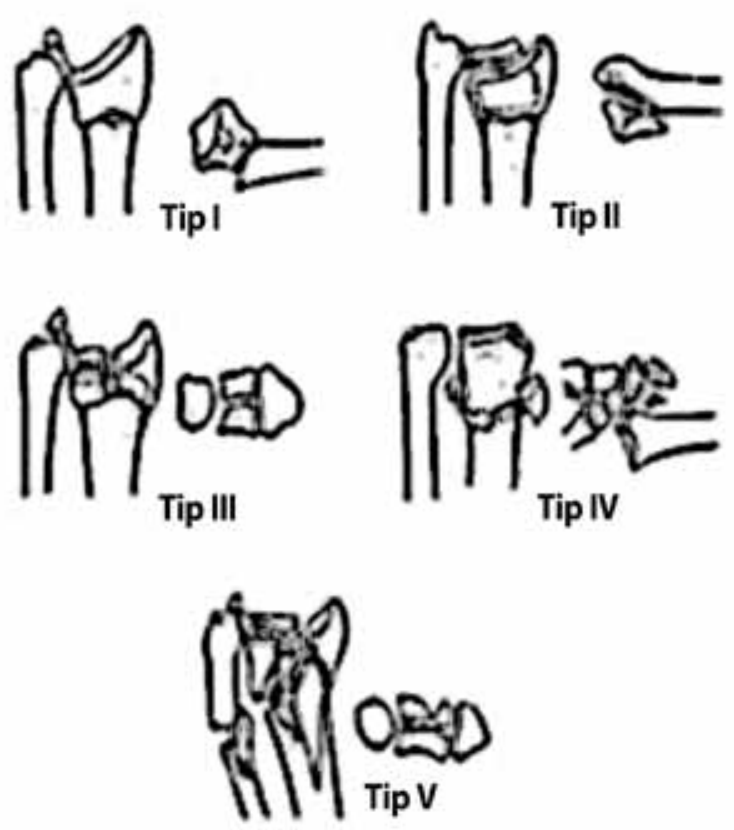

Şekil 3. Fernandez sınıflandırması (Fernandez DL. Fractures of the distal radius: operative treatment. Instr Course Lect 1993;42:7388.' 'den esinlenerek yeniden yapılmışır).

bu düzgünlüğün alçı içinde korunmasıdır. Alçı içinde kırığın redüksiyonunu korur bir şekilde durması ancak alçının temas etkisi, yumuşak dokuların gerginliği ve yumuşak doku kılıfının hidrolik basıncı sayesinde olabilir. Stabil kırıklar denildiğinde, kaymamış veya kaymış ama redüksiyon manevraları ile düzeltilip pozisyonu alçı içinde korunabilen kırıklar ile, $5^{\circ}$ 'den az dorsal açılanma ve $2 \mathrm{~mm}$ den az kısalma gösteren eklem dışı kırıklar anlaşılır. Başlangıç grafisinde parçalanma ve aşırı açılanma gösteren veya eklem içine uzanan kırıklar, ulnada eşlik eden kırıklar veya ileri derece osteoporozu olan kırıklar, stabil olmayan kırıklardır ve bu, alçı içinde ikincil kayma ihtimali yüksek kırıklar anlamına gelir (Şekil 4, 5). ${ }^{[5-9]}$

Konservatif tedavinin endikasyonları; 1) kaymamış eklem dışı ve eklem içi kırıklar, 2) kaymış ama kapalı redüksiyondan sonra stabil olan kırıklar ve 3 ) yaşlıların stabil olmayan kırıklarıdır. ${ }^{[5,9]}$

Kaymamış veya çok az kaymış ( $5^{\circ}$ 'den az dorsal açılanma veya 2 mm'den az kısalma gösteren) kırıklar alçı ile tedavi edilebilirler (Şekil 4). Bu kırıkların konservatif tedavi sonuçları ve uzun dönem prognozları çok iyidir. Alçı ya da özel yapım ateller kullanılabilir. ${ }^{[5]}$ illeriye dönük (prospektif) randomize bir çalışmada, çok az kaymış kırıkların klinik ve radyolojik sonuçları özel yapım 

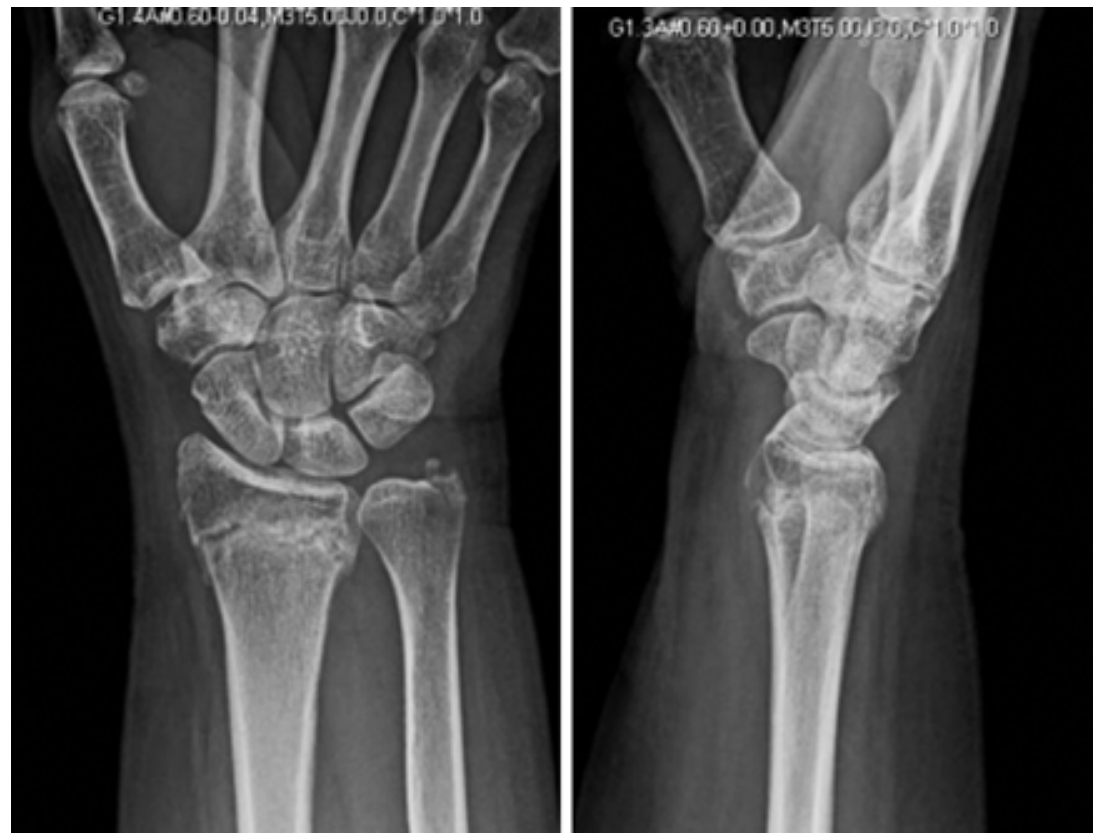

Şekil 4. Stabil bir distal radius kırı̆̆ı.

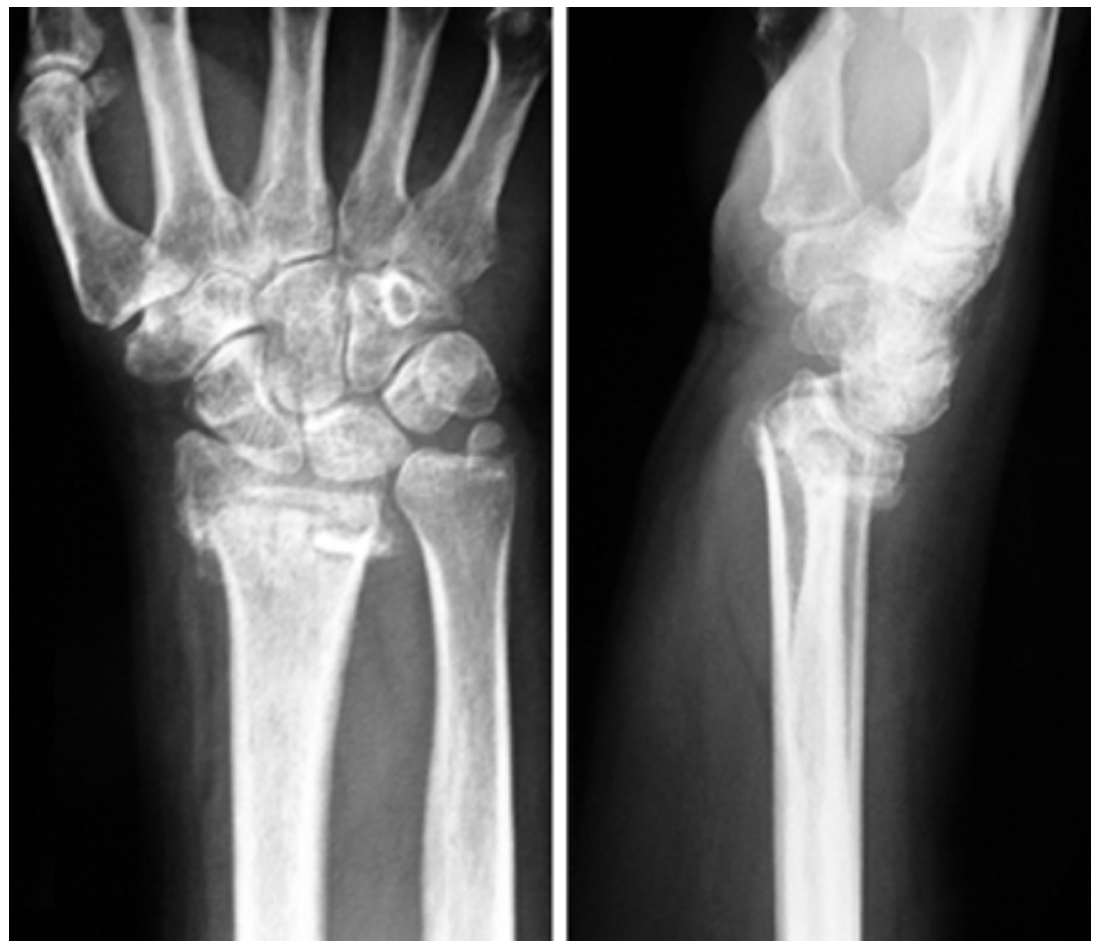

Şekil 5. Stabil olmayan bir distal radius kırı̆̆ı.

atellerde alçıya göre daha iyi bulunmuştur. ${ }^{[10]}$ Kaymış ama kapalı redüksiyondan sonra alçının içinde pozisyonu korunabilen kırıklar 5-6 hafta süre ile alçı, 2-3 hafta da çıkarılabilir atel ile tedavi edilebilirler. İkincil kaymanın kabul edilebileceği ve semptom vermeyecek fonksiyonel yanlış kaynamanın sorun olmayacağı yaşlı hastaların stabil olmayan kırıkları da, kapalı redüksiyon ve alçı tespiti ile tedavi edilebilirler; çünkü yaşlı kişilerin kemik kalitesindeki düşüklükten dolayı daha düşük enerjili ve genellikle eklem içine uzanmayan kırıkları olur ve sıklıkla başka genel sağlık sorunları da vardır. Aynı zamanda, yaşlı hastaların radyolojik ve fonksiyonel sonuçları arasında bir paralellik tespit edilememiştir. Bu nedenlerden dolayı, yaşlı hastaların 
kırıkları genellikle konservatif olarak tedavi edilir. Eklem içi ve diğer stabil olmayan kırıklarda konservatif tedavi uygulanması tercih edilmez. ${ }^{[5,7,9,11]}$ Doksan hastanın katıldığı ileriye dönük randomize bir başka çalışmada, eklem içi kırıklarda uygulanan konservatif tedavinin başarı şansının sadece \%43 olarak tespit edildiği bildirilmiştir. ${ }^{[12]}$

Lokal, bölgesel veya genel anestezi ile önce uygun ağrı kontrolü yapılır. Lokal hematom bloğu, ciddi şişliği olmayan düşük enerjili kırıklarda tercih edilir. Hematom bir miktar aspire edildikten sonra adrenalinsiz lokal anestezik maddeler kullanılır. Lokal anestezinin dezavantajları, yetersiz anestezi ve kas gevşemesinin sağlanamamasıdır. Zor redükte edilecek kırıklarda, geç redüksiyonlarda, kaymış kırıkların yeni redüksiyon manevralarında ve ödem, kontüzyon, açık yara gibi lokal yumuşak doku sorunu olanlarda, aksiller blok anestezisi gibi bölgesel anestezi tercih edilir. Çocuklarda ve lokal anesteziklere alerjisi olanlarda ise genel anestezi kullanılır. ${ }^{[5,8]}$

Redüksiyon manevraları ya direkt elle yerleştirme ya da ekstremiteyi traksiyon kulelerine asarak yapılır (Şekil 6,7). Elle direkt yerleştirme manevralarında, teorik olarak dorsale kaymış eklem dışı kırıklarda, Sir

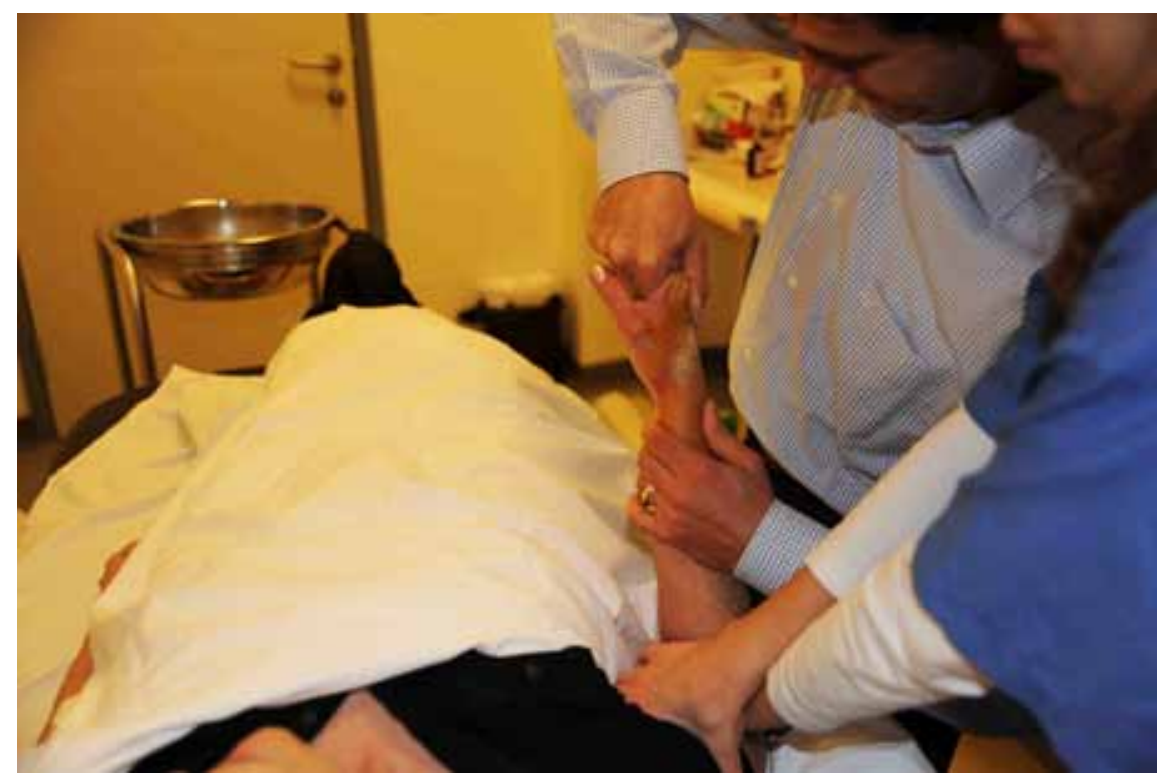

Şekil 6. Kapalı redüksiyon yapılmakta olan distal radius kırı̆̆ı.

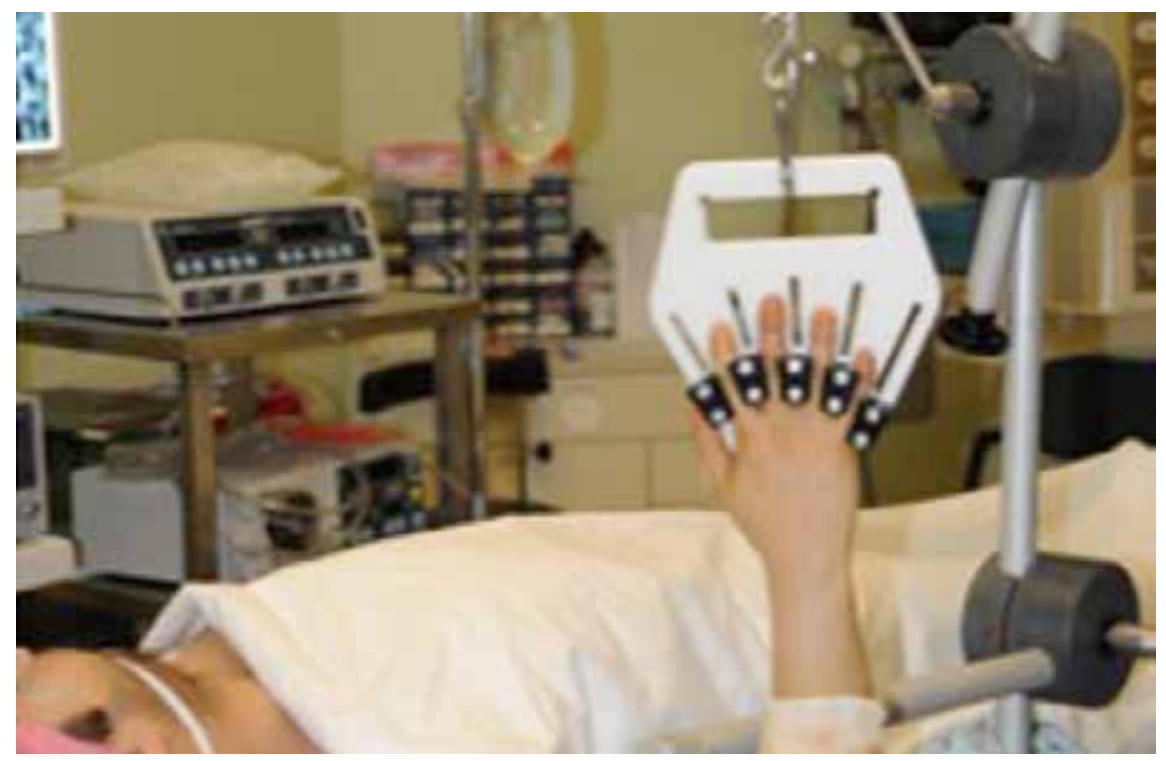

Şekil 7. Traksiyon kulesine asılarak yapılan kapalı redüksiyon. 
Robert Jones'un tekniği kullanılır. Bu teknikte ön kol pronasyondadır. Eğer kırık volare kaymış ise, manevra ön kol supinasyonda iken yapılır. Traksiyon kulelerinde uygulanan teknik ise skopi kontrolünde traksiyon altında yapılır. ${ }^{[5,13]} \mathrm{Bu}$ iki tekniğin karşılaştırıldığı ileriye dönük, kontrollü, randomize bir çalışmada, ilk hafta ve beşinci hafta sonunda radyolojik olarak istatistiksel anlamlı bir fark olmadığı bulunmuştur. Beşinci hafta bittiğinde traksiyon ile yapılmış redüksiyon kırıklarının sadece \%27'sinin, elle manipülasyon yapılmış kırıkların ise \%32'sinin radyolojik olarak kabul edilebilir pozisyonda olduğu görülmüştür. ${ }^{[14]}$

Alçı içindeki el bileği pozisyonu, alçının proksimal ve distal sınırları ve tespit süresi konularının tam olarak belirlenmesi gerekir. Dorsale açılanması olan, dorsal metafizde parçalanması olan kırıklarda el bileği $15^{\circ}$ fleksiyon, $10-15^{\circ}$ ulnar deviyasyon ve $25^{\circ}$ pronasyon pozisyonunda tespit edilir (Şekil 8). Aşııı derecede fleksiyon ve ulnar deviyasyon pozisyonunun (Cotton-Loder position) radyolojik olarak redüksiyonu korumasında belirli avantajları olmasına karşın, karpal tünel içinde aşırı basınç artmasına neden olarak, medyan sinirin etkilenmesi ve parmakların hareketinin zorlaşması gibi ciddi dezavantajları vardır (Şekil 9). ${ }^{[5,8]}$ Gelberman ve arkadaşları, el bileği nötral pozisyondayken $18 \mathrm{mmHg}$ olarak ölçtükleri karpal tünel basıncını, el bileği $20^{\circ}$ fleksiyondayken $27 \mathrm{mmHg}, 40^{\circ}$ fleksiyondayken ise $47 \mathrm{mmHg}$ olarak tespit etmişlerdir. ${ }^{[15]}$ Gupta'nın 204 olguluk ileriye dönük randomize çalışmasında, dorsifleksiyon pozisyonunda tespit etme ile radyolojik olarak göz ardı edilebilecek bir redüksiyon kaybının söz konusu olduğu, ama bununla birlikte çok hızlı bir fonksiyonel iyileşme gösterdiği rapor edilmiştir.[16] Genel olarak, pozisyondan ziyade kırığın düzeltilmiş hali ve sürdürülebilirliği önemlidir. Alçı, distal avuç içi çizgisinin distaline geçmemeli, metakarpofalangeal (MF) eklemin tam fleksiyonuna izin verecek şekilde olmalıdır (Şekil 10). MF eklemlerin hareketinin engelleneceği kadar distale uzanan alçı uygulamalarında, çok hızlı bir şekilde parmak sertlikleri gelişir; dirsek üstü veya dirsek altı olmasının önemi yoktur, çünkü önemli olan alçı içindeki kırığın stabilitesidir. Genellikle 2-3 hafta sonra şişlik iner ve alçı bollaşmaya başlar. Bu durumda alçının etkisini kaybetmesi ve kırık pozisyonunun kayması tehlikesi vardır. Illk üç hafta hastanın sık takip edilmesi, bollaşmanın erken fark edilmesi ve kırık redüksiyonu
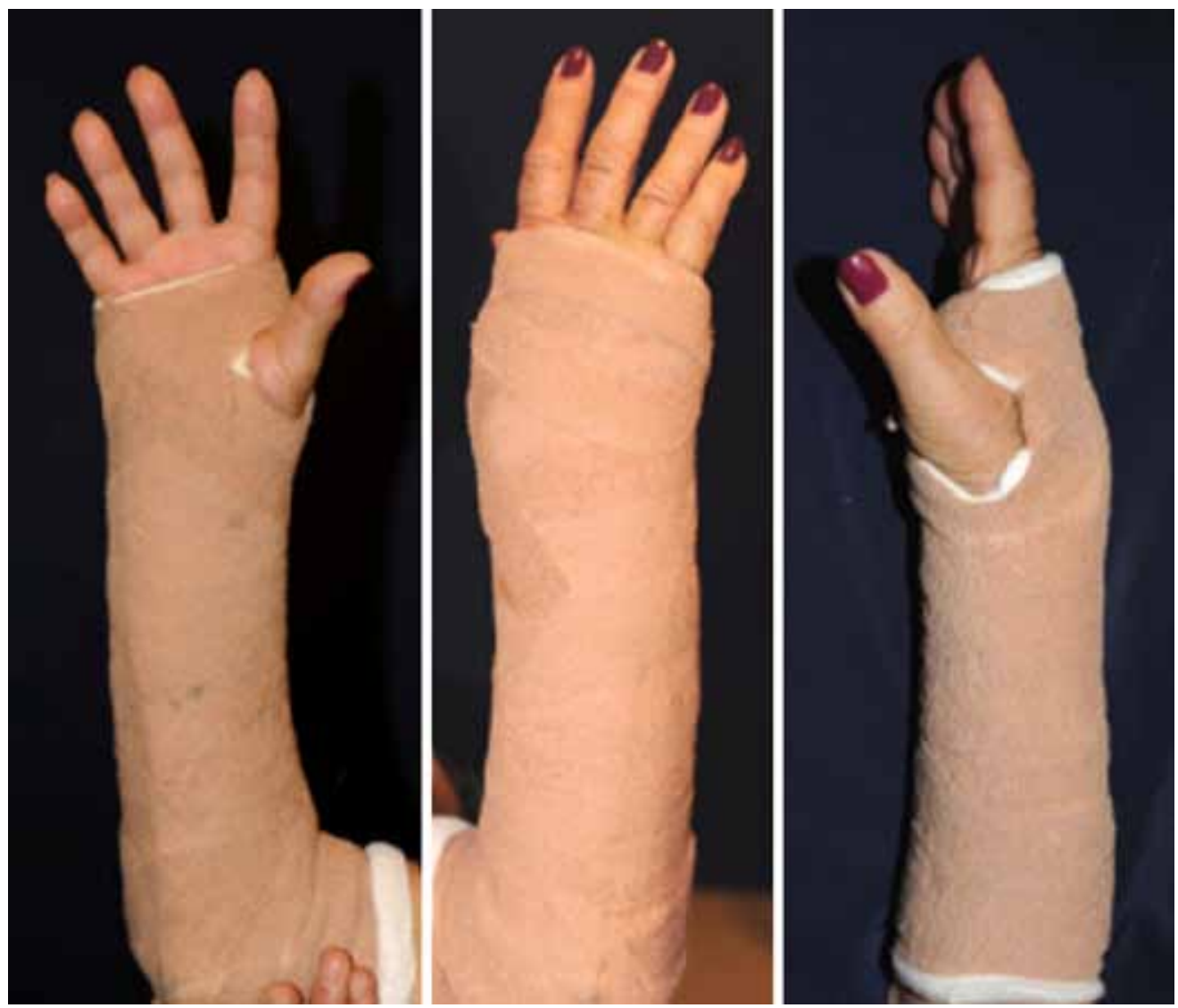

Şekil 8. Alçının içinde el bileğinin pozisyonu. 

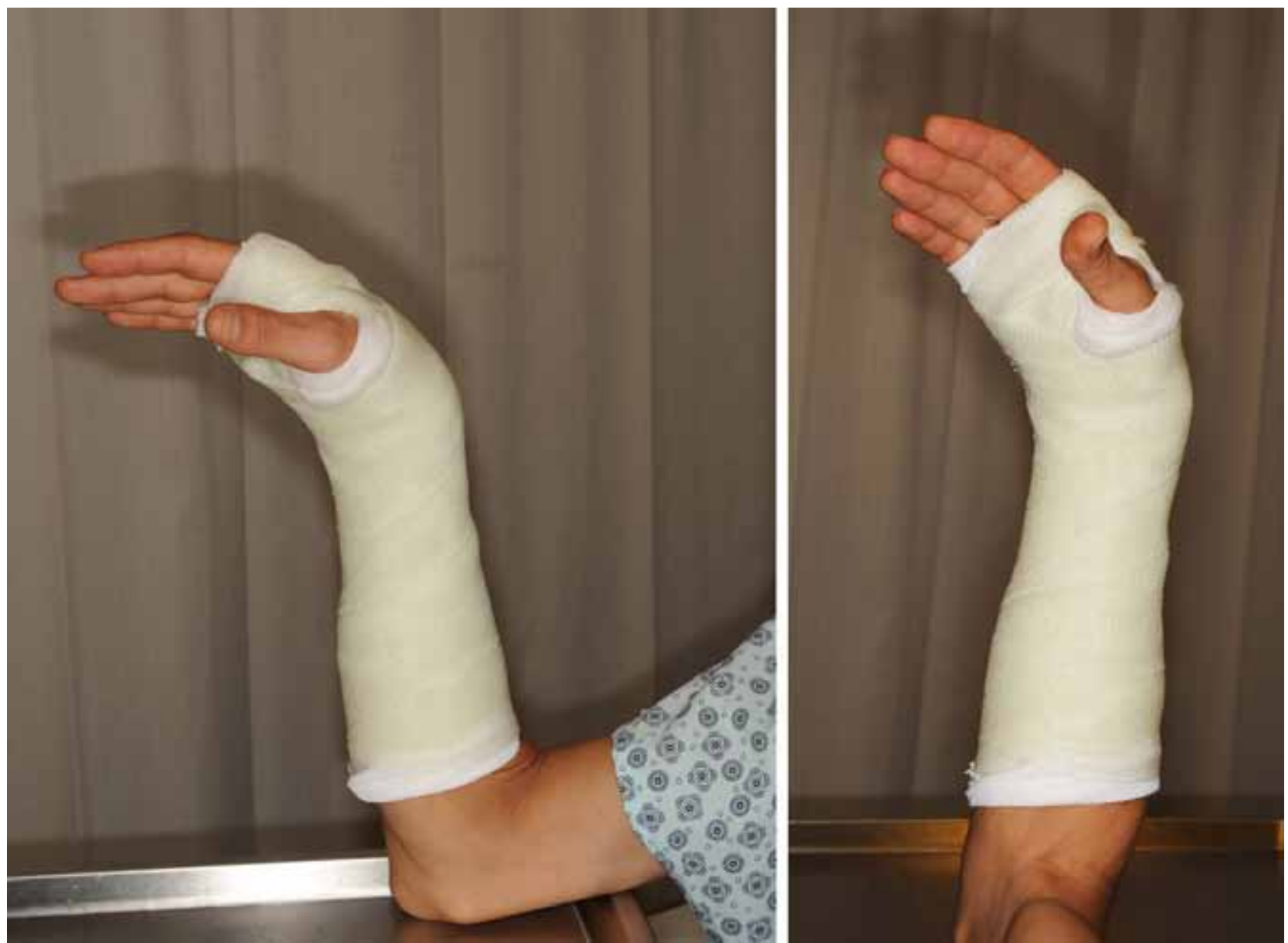

Şekil 9. Cotton-Loder pozisyonu.
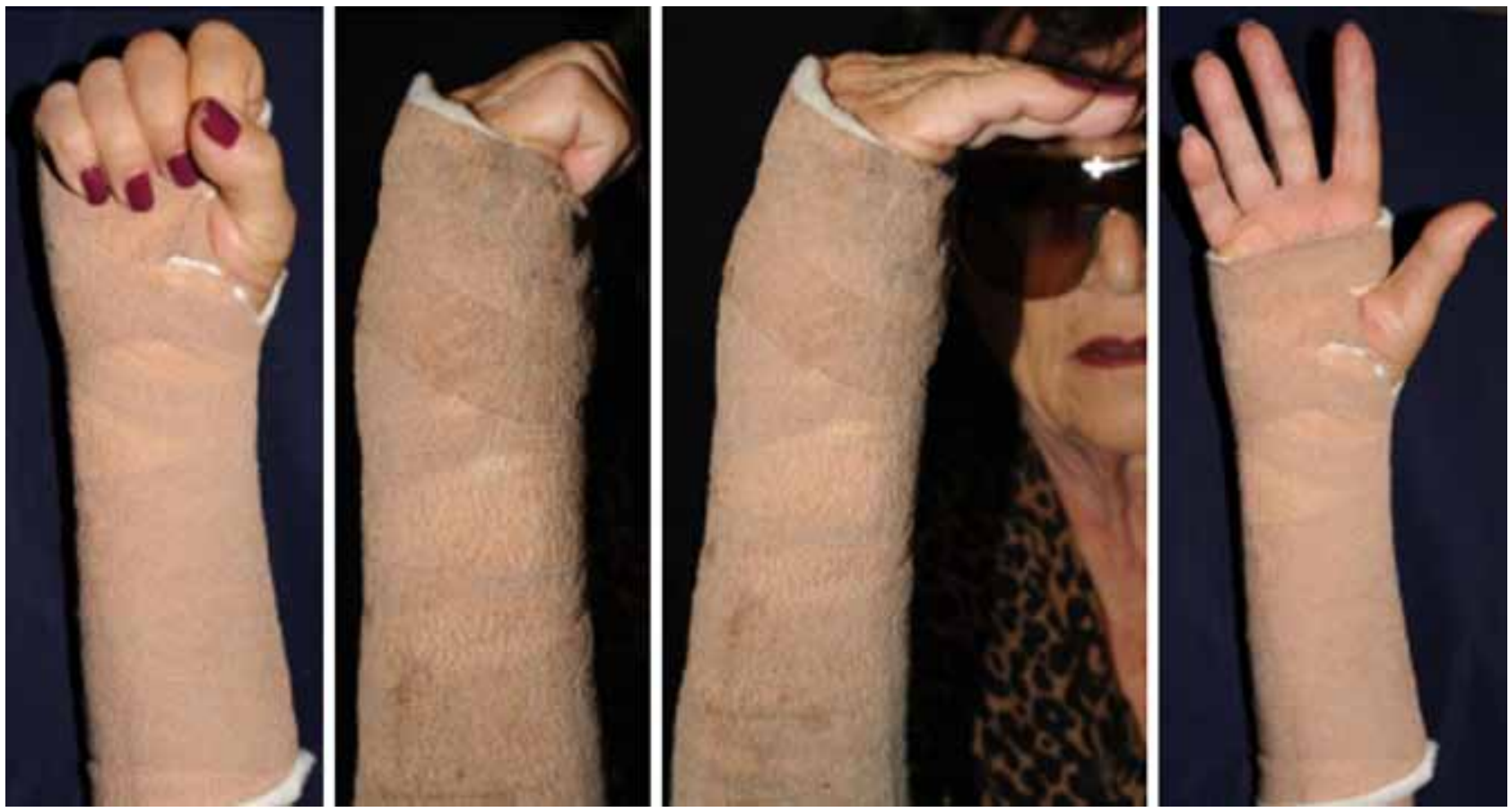

Şekil 10. Alçının içinde parmakların hareketi. 
bozulmadan önce alçının değiştirilmesi çok önemlidir. [5,8,9] Parçalı kırıkların konservatif tedavi edildiği 60 hastalık bir seride, 53 kırı̆ıı ilk hafta içinde pozisyonunu kaybettiği bulunmuştur. ${ }^{[17]}$ Alçı içinde kayma olursa, ilk üç hafta içinde tekrar redüksiyon denenip alçılama yenilenebilir. Ama alçı içinde kaymanın nedeni kırığın stabil olmaması ise, konservatif tedavi seçimi zaten yanlış demektir; yeni redüksiyon ve alçı girişimi de başarısız olacaktır; ama bollaşma ve alçılama hatası ise tekrar deneme işe yarayabilir. Tespit süresi güvenli kaynamanın sağlanması ile ilişkilidir. Bu tedavi ile kaynama, ikincil iyileşme yani kırık kaynama dokusu (kallus) gelişmesi ile olur. Yumuşak kırık kaynama dokusu üçüncü haftada gelişir. Kırığın tipine ve radyolojik iyileşme düzeyine göre en az altı hafta tespit gerekir. ${ }^{[5]}$

Rehabilitasyonun birinci dönemi (Dönem 1) olan tespit döneminde hastalara yukarıda anlatılan şekilde altı hafta alçı uygulanır. Alçı içinde MF, proksimal interfalangeal (PiF), distal interfalangeal (DiF) eklemlere tek tek ve kombine olarak aktif fleksiyon - ekstansiyon egzersizi uygulanır (Şekil 11). Aktif parmak hareketleri ağrı sınırında uygulanmalıdır. El bileği fleksiyon ve ulnar deviyasyondayken ekstansör tendonlar gerildiği için aşırı fleksiyon ağrılı olabilir. Aktif parmak hareketlerinin yanında fleksör tendon kaydırma egzersizleri, intrensek germe egzersizleri, başparmak opozisyon egzersizleri
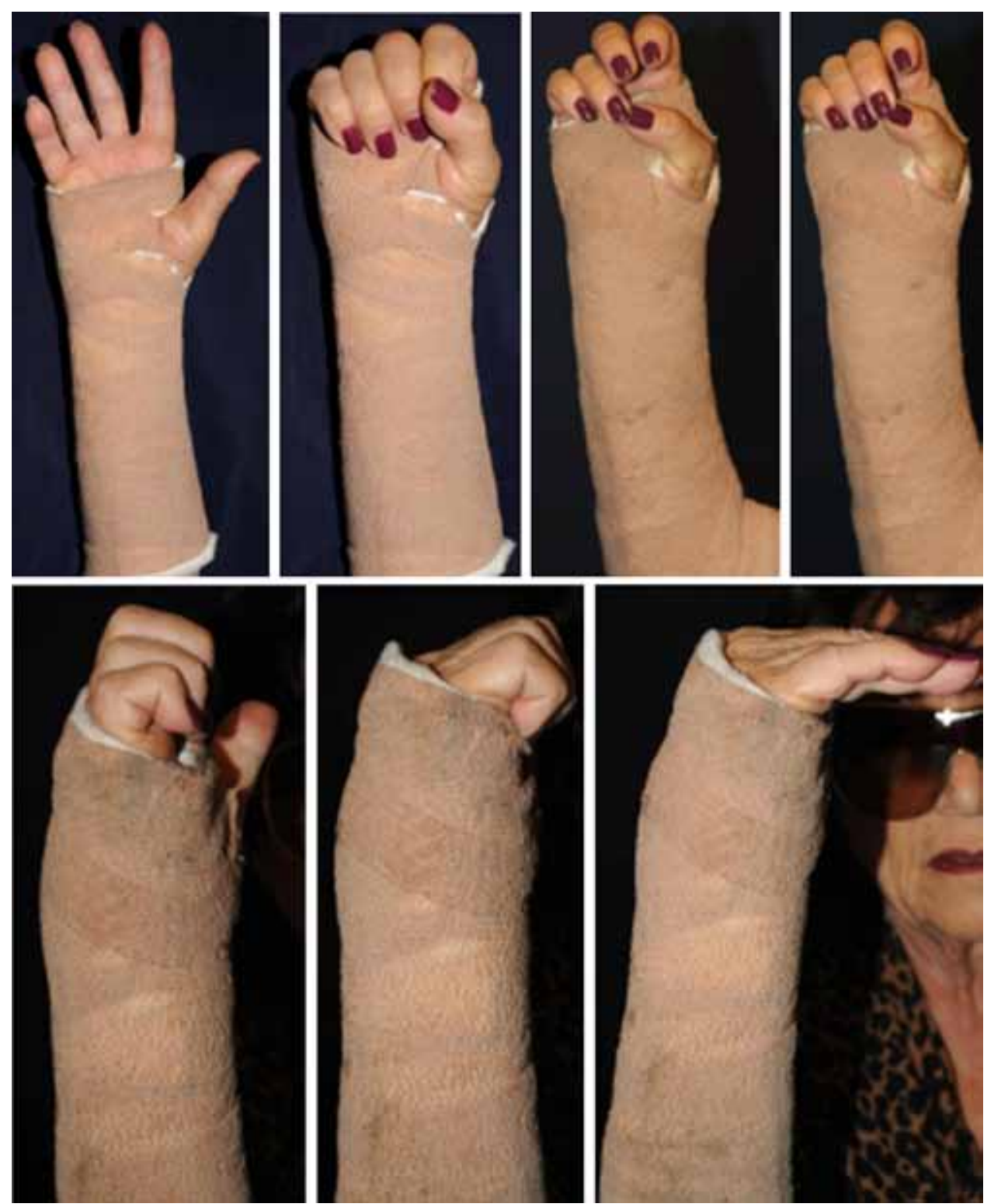

Şekil 11. Alçı içinde parmak egzersizleri. 
de bu dönemde uygulanan diğer egzersizlerdir. Travma sonrası erken dönemde artan ödem ve inflamasyon karpal tünel içi basıncını zaten arttırdığından, bu dönemde elevasyon çok önemlidir. Hastalar medyan sinir sıkışma semptomları açısından izlenmelidir. Aynı zamanda, etkilenen tarafta dirsek ve omuz eklemlerine aktif eklem hareket açıklığı (EHA) egzersizleri de uygulanmalıdır. Dolaşımı olumsuz yönde etkilememek ve ulnar siniri aşırı germemek için, hastalara dirseği aşıı derecede fleksiyonda tutmamaları gerektiği söylenmelidir. ${ }^{[4]}$

Kırık iyileşmesi röntgen tetkiki ile kontrol edildikten sonra 6. hafta bitiminde alçı çıkartılır. Yumuşak kallusun hakim olduğu Dönem 2'de kırık hattı henüz zayıftır. Bu nedenle alçı çıkarıldıktan sonraki iki hafta hastalara el/el bileği ateli uygulanır. Dönem 1 egzersizlerine ek olarak, ağıı sınırında aktif, yardımlı EHA egzersizlerine başlanır. Tenodez egzersizleri ile fleksör ve ekstansör tendonların kayması sağlanır. Hastaların durumuna göre, egzersiz öncesinde yüzeysel sıcak veya soğuk uygulama (sıcak veya soğuk paketler, çalkantılı su banyoları), ultrasonografi (US), TENS (transcutaneous electrical nerve stimulation) gibi fizik tedavi yöntemleri seçilerek uygulanabilir. Rehabilitasyon sürecini, hastanın yaşı, kemik yoğunluğu, ağrıya karşı toleransı, sahip olduğu sistemik hastalıklar yakından etkiler. Özelikle bu dönemde el bilek hareketleri ileri derecede ağrılı olabilir. El bileğine yönelik egzersizlerin ağrı sınırında yapılması önemlidir. ${ }^{[4,18]}$

Sekizinci haftadan sonra Dönem 3'e girilir. Bu dönemde kırık kaynama dokusu sertleşmeye, kırığın sağlamlığı orta düzeye ulaşmaya başlar. Dönem 2 egzersizlerine ek olarak el bileğine germe egzersizleri, hafif kuwetlendirme egzersizlerine başlanabilir. Kuwvetlendirme egzersizleri için kırık stabilitesinden emin olunmalıdır. Klasik bilgide, fizyolojik el bilek hareketleri sırasında bileğe binen yük 88-135 N (Newton)'dir. ${ }^{[19]}$ Kurvetli kavrama ile distal radiusa uygulanan kuwet 2410 N'ye ulaşır. ${ }^{[20]}$ $\mathrm{Bu}$ nedenle, kuwetlendirme egzersizlerine kırık iyileşmesinden emin olduktan sonra başlanmalıdır. Bu süre de genellikle 10. haftadan sonra olmaktadır. Dönem 3'te (8-10 hafta) el bilek fleksiyonu veya ekstansiyonu $30^{\circ}$ 'den az ya da supinasyon veya pronasyonu $60^{\circ}$ 'den az ise, dinamik veya statik ilerleyici (progresif) atel uygulamalarına başlanması önerilir. ${ }^{[4,18]}$ Biz klinik uygulamamızda atel uygulamaları yapmıyoruz. Hastalarımızın EHA'sını arttırmaya yönelik uzun süreli germe egzersizleri ve antagonist kasların kuwvetlendirilmesi uzerinde duruyoruz. Buna ek olarak, hastaların evde sık aralıklarla uygulamaları gereken "ev ödevi germe" yöntemlerini öğretip, ev programı hazırlıyoruz. Kısıtlılıkları açmak için yardım aldığımız diğer bir tedavi yöntemi olarak PNF (progressive neuromuscular facilitation) tekniklerinden "kas-gevşe" yöntemi ve el bileği eklem hareketlendirme teknikleri uyguluyoruz (Şekil 12).

Kavrama gücünün iyileşmesi uzun süre alabilir. Bir çalışmaya göre, altı ay sonunda karşı tarafın \%46'sı, bir yıl sonunda ise \%68'i olarak ölçülmüştür. ${ }^{[21]}$ Knirk ve Jupiter, genç yaştaki hasta grubunda yedi yıl sonunda karşı sağlam tarafa göre $\% 41$ kavrama gücü kaybı rapor etmişlerdir. ${ }^{[22]}$

El bileği hareket genişliliği iyileşmesinin kırığın şiddeti ve ciddiyeti ile ilişkili olduğu gösterilmiştir. Alçı çıkarıldıktan sonra normal el bileği hareket genişliğinin $\% 40$ 'ı, üç ay sonra $\% 74$ 'ü, altı ay sonra $\% 80$ 'i ve bir yıl sonra da \%83'ünü hedeflemek, hasta ve tedavi eden grubun beklentilerine ışık tutabilir. ${ }^{[22]}$

Konservatif tedavideki başarı, hasta seçiminin doğru yapılmasına ve doğru endikasyonlar dahilinde uygulanmasına bağlıdır. Belirli ölçütler olmasına rağmen,
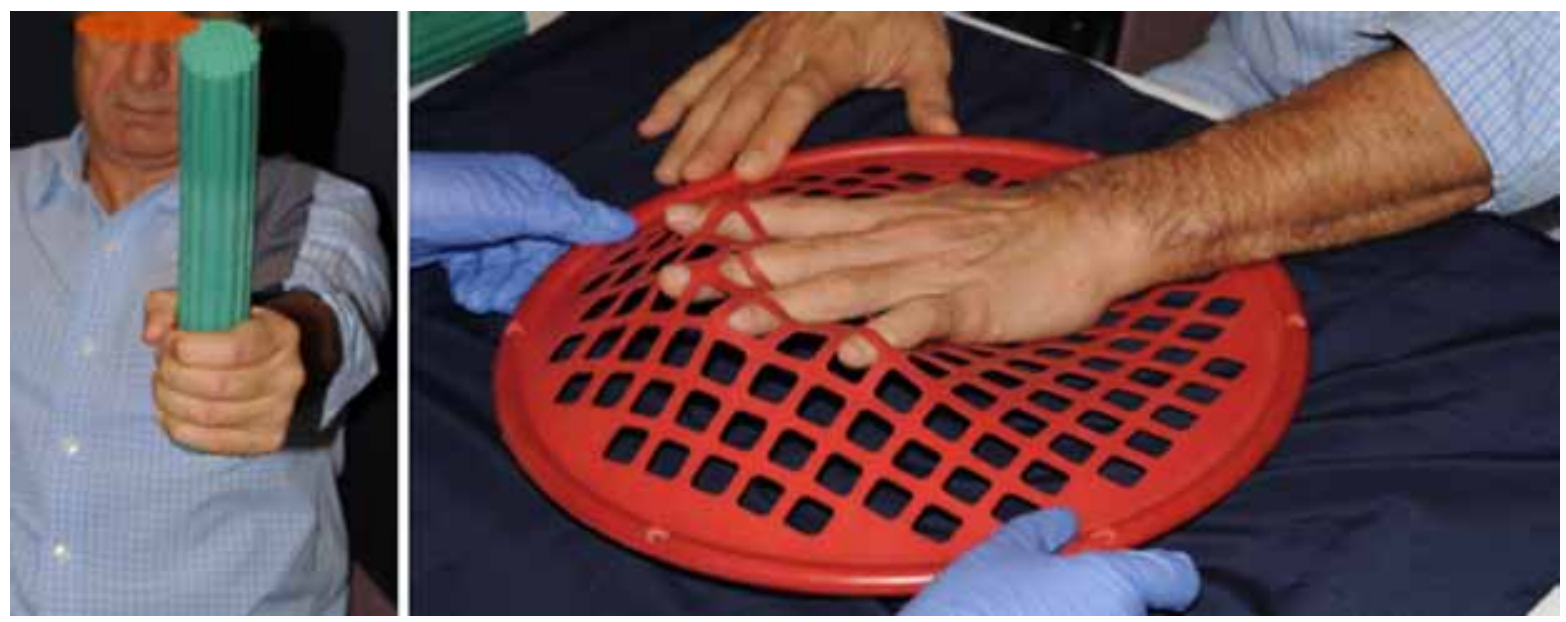

Şekil 12. PNF teknikleri. 
hastanın yaşı, işi, kemik kalitesi ve fonksiyonel gerekliliklerine göre karar verilmelidir. Bu tedavide görülebilecek komplikasyonlar ve sorunlar; yanlış kaynama, DRUE'de ağrı, medyan sinir basısının yaratacağı problemler, karpal stabilitede bozukluk ve tendon kopmalarıdır. ${ }^{[5,8,9]}$

\section{KOMPLIKASYONLAR ve SORUNLAR}

Radiusun distal ucunda oluşan kırıklar vücutta en sık görülen kırıklardan birisidir. Literatürde bu kırıklara bağlı gelişen komplikasyonların \%6-80 arasında görüldüğü rapor edilmektedir. ${ }^{[23,24]}$ Bu komplikasyonlar kırığa veya tedaviye ait olabilir. Ardışık 250 olgunun değerlendirildiği bir çalışmaya göre, \%27 oranında doktorların belirlediği, \%21 oranında da hastaların belirlediği komplikasyon oranları rapor edilmiştir. Doktorlar genellikle tanı üzerinde dururken, hastalar doğal olarak şikayetlere odaklanmışlardır. ${ }^{[24]}$ Komplikasyonlar; akut, erken (altı haftadan önce) ve geç dönem (altı haftadan sonra) olarak sınıflandırılabilir. ${ }^{[25]}$

\section{Akut dönem komplikasyonları}

\section{Sinir yaralanmaları}

Bildirilen oranlar \%0-17 arasındadır. Daha çok medyan sinir, daha sonra radyal, en az da ulnar sinir
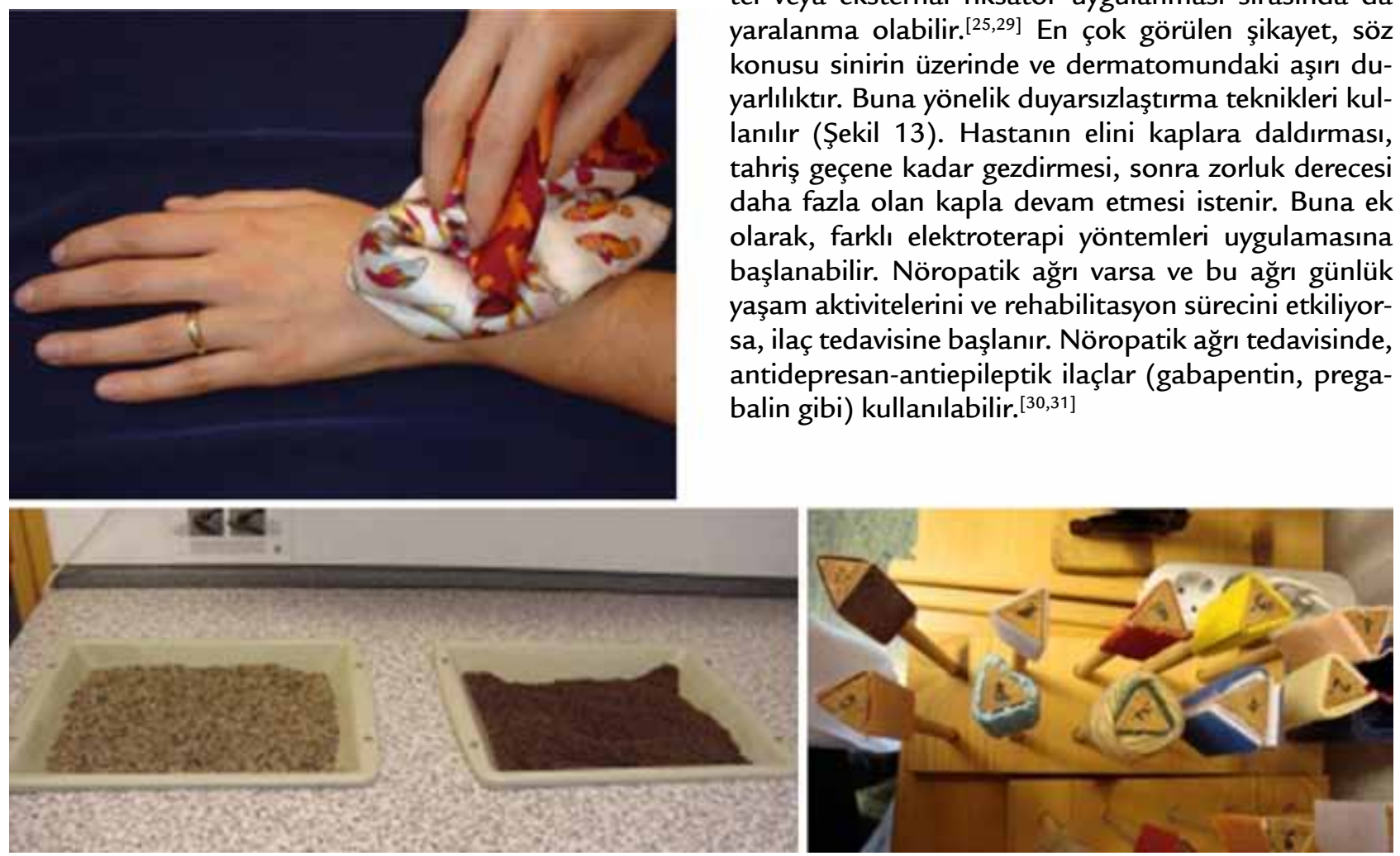

Şekil 13. Duyarsızlaştırma tekniklerini uygulamada kullanılan kitler ve materyaller. etkilenmeleri görülür. ${ }^{[24]}$ Karmaşık, parçalı kırıklarda ve sık yapılan kapalı redüksiyon manevralarından sonra en sık görülen sorun, akut karpal tünel sendromudur (KTS). Fakat KTS'nin sinir yaralanmasından ayırıcı tanısının yapılması gerekir. Yukarıda da bahsedildiği gibi, karpal tünel içindeki basınç artışından dolayı el bileğinin aşırı derece fleksiyon pozisyonlanmasından kaçınılmalıdır. ${ }^{[15,25,26]}$

Hafif derecedeki KTS şikayetleri, genellikle medyan sinir etrafındaki şş̧liğe ve ezilmeye bağlıdır. El ve el bileğinde hatırı sayılır şişlik varsa, tam alçı yerine ateller veya her iki tarafından kesilerek iki ayrı kapak haline getirilmiş alçılar tercih edilir. Hastaların ellerine kalp seviyesinin üzerinde elevasyon yapmaları ve aktif parmak hareketlerini uygulamaları konusunda sık uyarılar çok önemlidir. Şişlik geçince genellikle şikayetler de azalır. Şikayetler çok ciddi ve ilerleyici ise veya zaten kırığa cerrahi tedavi yapılacaksa, karpal tünelin gevşetilmesi değerlendirilmelidir. Erken gevşetmenin prognozu daha iyidir. Eğer geç gevşetmeye bağlı olarak sinir uzun süre baskı altında kalmışsa, şikayetlerin geçmesi uzun zaman alabilir veya tam olmayan iyileşmeler görülebilir. ${ }^{[27-29]}$ bağımsız olarak etkilenebilir. Kötü alçı veya atel uygulamasına bağlı olarak sinirde nörit gelişebileceği gibi, radyal stiloid seviyesinde veya başparmak dorsal yüzünde sıkışma gelişebilir. Bununla birlikte perkütan tel veya eksternal fiksatör uygulanması sırasında da yaralanma olabilir. ${ }^{[25,29]}$ En çok görülen şikayet, söz konusu sinirin üzerinde ve dermatomundaki aşırı duyarlııktır. Buna yönelik duyarsızlaştırma teknikleri kullanılır (Şekil 13). Hastanın elini kaplara daldırması, tahriş geçene kadar gezdirmesi, sonra zorluk derecesi daha fazla olan kapla devam etmesi istenir. Buna ek olarak, farklı elektroterapi yöntemleri uygulamasına başlanabilir. Nöropatik ağrı varsa ve bu ağrı günlük yaşam aktivitelerini ve rehabilitasyon sürecini etkiliyorsa, ilaç tedavisine başlanır. Nöropatik ağrı tedavisinde, antidepresan-antiepileptik ilaçlar (gabapentin, pregabalin gibi) kullanılabilir. ${ }^{[30,31]}$
Radyal sinirin dorsal duyu dalı, tedavinin şeklinden 
Ulnar sinir hasarı, distal radius kırıklarında sinirin anatomik yerleşimi nedeniyle daha nadir görülür. Yüksek enerjili kırıklarda, kırık parçanın dorsale yer değiştirdiği olgularda ulnar sinir yaralanabilir. ${ }^{[29]}$

\section{Kompartman sendromu}

Nadir görülen ama sonuçları çok ciddi olabilen bir komplikasyon olan kompartman sendromu konusunda, literatürde en geniş çalışmalardan biri 6395 distal radius kırığı olgusunun değerlendirilmesidir. On altı olguda $(\% 0,25)$ kompartman sendromu tespit edilmiş, bunların $15^{\prime} i$ ön kolda, biri ise elde görülmüştür. ${ }^{[32]}$ Ödem ve şişliğin engellenmesi için, tam olmayan alçıların tercih edilmesi, elevasyon ve yakın takip önemlidir. ilk 54 saate kadar bildirilmiş olgular olduğu için, başlangıçta 2-3 gün çok iyi izlenmeli, hastalar ağrı kesicilerin etki etmeyeceği ağrı, şişlik ve parmaklardaki renk değişikliği konusunda uyarılmalıdır. Sıradışı ağrıdan başka, parmakların pasif ekstansiyonunda aşııı derece ağrı oluşması en tipik bulgulardır. Kompartman sendromundan şüphe edilirse, hemen tüm alçı ve sargılar çıkarılmalı, ekstremite elevasyona alınmalıdır. Eğer şikayet ve bulgular devam ederse, kompartman içi ölçüm cihazları kullanarak basınç yüksekliği de onanırsa, cerrahi dekompresyon endikasyonu vardır. ${ }^{[25,33]}$

\section{Birlikte görülen başka yaralanmaların gözden kaçması}

Düşme şekli ile ilgili olarak, dirsekte, omuzda veya alt ekstremitede başka kırıklar veya karpal kırık ve bağ yaralanması olasılığı için de dikkatli muayene ve inceleme yapılmalı, başka travmalar gözden kaçırılmamalıdır. ${ }^{[25]}$

\section{Erken dönem komplikasyonlar (6 haftadan önce)}

Tam alçının, kırıkları daha iyi tespit etmesine rağmen, şişliğe karşı genişleme yeteneği yoktur. Bu nedenle, hastalar alçının sıkıştırmasına bağıı ağıı, sinir basısına bağlı uyuşma ve karıncalanma, şişlik şikayetleri için uyarılmalıdırlar. Tam olmayan atel şeklindeki alçılar kırı̆̆ı daha az stabil tutmalarına rağmen, şişliğe karşı daha emniyetlidirler. Alçıya bağlı olan diğer bir sorun da parmakların hareketine engel olma olasılığıdır. Alçı, MF eklemleri açıta bırakacak ve parmakların aktif/pasif hareketine engel olmayacak şekilde olmalıdır. Aksi taktirde parmaklarda sertlikler ve distrofi problemleri ciddi boyutta olabilir. ${ }^{[25]}$

Ayrıca, başlangıçta elle yapılan düzeltme (manipülasyon) ile sağlanan pozisyon kayabilir. Bu durumda, ya alçı çıkarılıp tekrar düzeltilir ya da ameliyat kararı verilir. illeri yaş, kırığın parçalı olması, kırığın başlangıçta aşırı kaymış olması gibi durumlar pozisyonun bozulma riskini arttıran etmenlerdir. ${ }^{[34,35]}$

\section{Tendon kopmaları}

Erken veya geç dönem komplikasyonu olarak görülebilir. Konservatif tedavi edilen kırıklarda başta EPL olmak üzere daha çok ekstansör tendonların kopması görülür (Şekil 14). Ekstansör tendon kopma görülme sıklığı \%0,07-0,88 arasında değişmektedir. ${ }^{[29]}$ Tendon

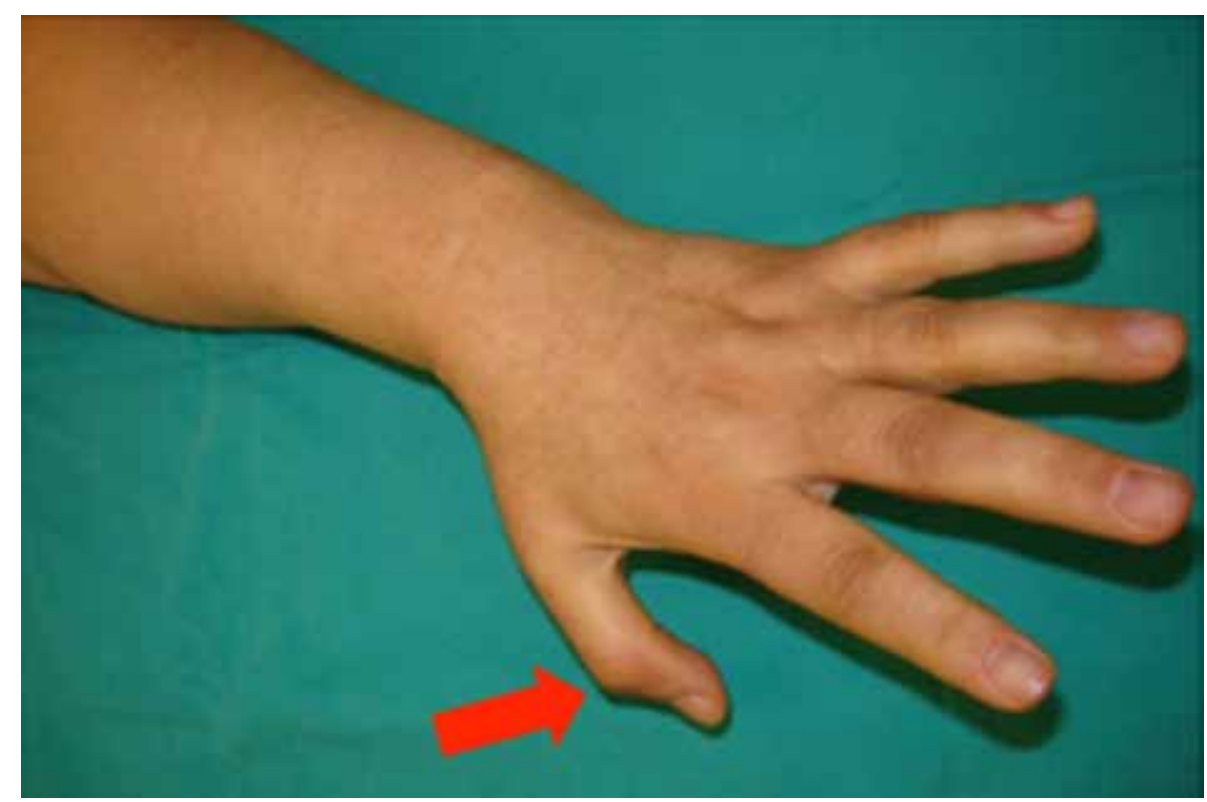

Şekil 14. Ekstensor pollisis longus tendon kopması gelişen hastanın başparmağını kaldıramaması (kırmızı ok). 
kopmaları literatürde mekanik ve vasküler olmak üzere iki teori ile açıklanmıştır. Mekanik teoriye göre, radiusun dorsal korteksinde oluşan sivri kemik çıkıntıları üçüncü ekstansör kompartmana doğru uzayarak kopmaya neden olur. Vasküler teoride ise, kırık kaynama dokusu veya hematomun üçüncü ekstansör kompartman basıncını arttırması ve EPL'nin beslenmesini bozarak kopmaya neden olması söz konusudur. ${ }^{[9,29]}$

Tendon kopması geliştiğinde, kopan tendon uçları genellikle düzensiz, yıpranmış ve incelmiş olduğundan, birincil uç uca onarım çoğunlukla mümkün olmaz. Bu durumda, tendon transferleri veya greft kullanılarak yapılan onarımlar gündeme gelir (Şekil 15). ${ }^{[25,29,36,37]}$

\section{Geç dönem komplikasyonlar (6 haftadan sonra)}

Kemik, eklem, yumuşak dokular ve sinirleri ilgilendiren geç komplikasyonlar nadir değildir.

\section{Karpal tünel sendromu}

Altmış hastalık bir derlemede, \%20 hastanın kırıktan ortalama 10 ay sonra başlayan şikayet gösterdiği ve bunların da elektrofizyolojik olarak ispat edilen karpal tünel sendromu olduğu bildirilmiştir. ${ }^{[38]}$

\section{Kompleks bölgesel ağrı sendromu}

Kompleks bölgesel ağrı sendromu (KBAS); bölgesel ağrı, otonom disfonksiyon, vazomotor değişiklikler, atrofi ve fonksiyonel kayıp ile karakterize, patognomik tanısal testi olmayan klinik bir tablodur. Bu sendrom, refleks sempatik distrofi, kozalji, algodistrofi olarak da bilinir. KBAS Tip I, sinir hasarı olmadan, ağrı, fonksiyonel yetmezlik, otonom fonksiyon bozukluğu ve distrofik değişikliklerle karakterize iken, KBAS Tip II'de tespit edilebilen sinir hasarı vardır (kozalji). KBAS Tip III ise tüm ekstremitelerde yaygın ağrı ile karakterizedir. ${ }^{[39,40]}$

Distal radius ve ulna kırıkları KBAS oluşumuna en sık yol açan yaralanmalardır. Distal radius kırıkları sonrasında KBAS Tip I veya Tip II görülme sıklığı ileriye dönük çalışmalarda \%18-39 arasında bulunmuştur. ${ }^{[41-43]}$ Burada; sıkı alçılar, medyan sinirin basısı, medyan veya ulnar sinir yaralanmaları, distal radyoulnar eklemde stabilite bozukluğu, eşlik eden ulna kırıkları, KBAS oluşmasına yol açabilir. Atkins ve arkadaşları, kırığın şiddeti ile KBAS gelişme sıklığı arasında ilişki bulamazken, Bickerstaff, ciddi kırıklarda KBAS oluşumunun daha fazla olduğunu belirtmiştir. ${ }^{[41,42]}$

KBAS'de hastalar hiperaljezi (normal ağrılı bir uyarana artmış ağrı yanıtı), allodini (normalde ağrı oluşturmayan bir uyaranın ağrı oluşturması), hiperestezi (uyarana artmış duyarlılık), hipoestezi (uyarana azalmış duyarlılık), hiperpati (uyarana artmış reaksiyon ve artmış bir eşik) gibi farklı ağrı biçimlerinden yakınabilirler. Ağrıyı tetikleyen bir kaynak veya sinir lezyonu varsa belirlenmelidir. Kas ve eklem sertliği, ödem, osteopeni, cilt ve tırnakta değişiklikler, kıllanmalar gibi trofik bozukluklar kliniğe eşlik edebilir. Etkilenen uzuvda ISI değişiklikleri (sıcak veya soğuk), terleme bozuklukları (aşırı terleme veya terlememe), vazomotor değişiklikler (kızarıklık veya morarma) gibi otonom fonksiyon bozukluğu belirtileri olabilir. ${ }^{[40,44]}$

KBAS tanısı öncelikle klinik olarak konur. Yardımcı tanı yöntemlerinden görüntüleme yöntemleri (röntgen, üç fazlı kemik sintigrafisi), elektrofizyolojik testler, termografi, sempatik bloklar, terleme testleri, algometre, dolorimetre kullanılabilir. Klinik olarak ayırıcı tanı yapılması gerektiğinde, bu yardımcı tanı yöntemleri seçilerek uygulanır. ${ }^{[40,44]}$

Tedavi planlanırken ağrının kontrol altına alınması; nöroma, sinir sıkışma sendromu, DRUE veya TFKK problemleri gibi noziseptif odakların tespit edilmesi ve ortadan kaldırılması, varsa deformitelerin tedavi edilmesi ve el fonksiyonlarının arttırılması hedeflenir. Medikal tedavi olarak antidepresanlar, antikonvülzanlar, membran stabilize eden ilaçlar, adrenerjik ilaçlar,
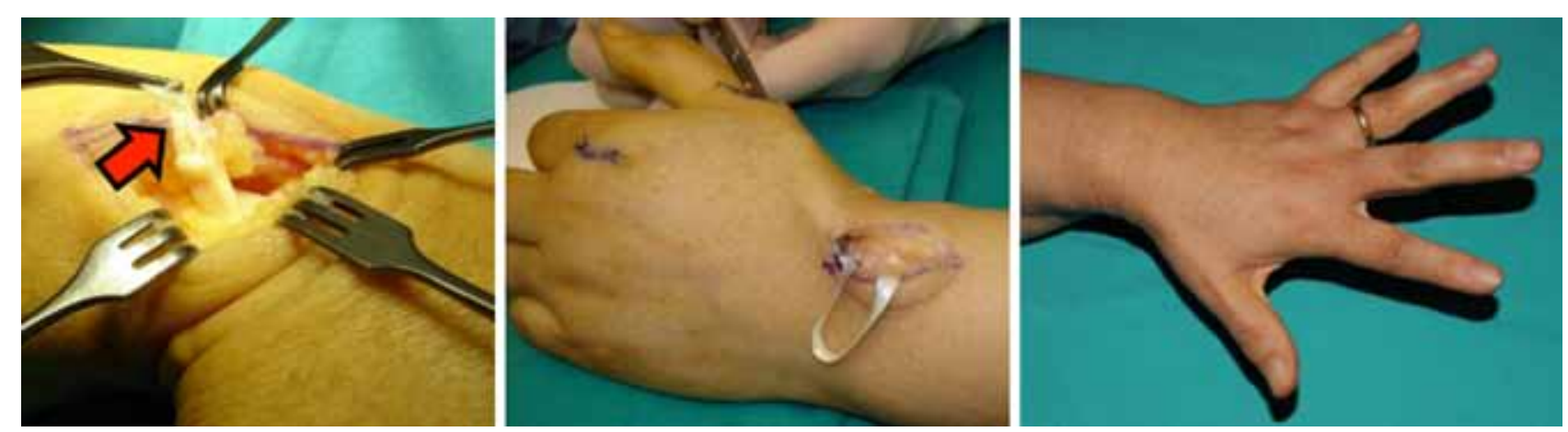

Şekil 15. Kopan tendon uçlarının düzensiz olması (en soldaki şekil, kırmızı ok). Ekstensor pollisis longus kopması için yapılan tendon transferi (ortadaki şekil) ve takiplerindeki fonksiyonel sonuç (en săgda). 
kalsiyum kanallarını bloke eden ilaçlar, nöromusküler blokaj yapan ilaçlar kullanılabilir. Oral medikal tedavi yanında, gangliyon blokajı, intratekal tedaviler, lidokain ile devamlı periferik bloklar gibi parenteral tedaviler uygulanabilir. Sempatektomi, periferik sinir uyarıcıları, omurilik uyarıcıları, ağrı kontrolünde kullanılmaktadır. Rehabilitasyon, medikal tedaviler ile beraber planlanır. Rehabilitasyonda aktif-pasif EHA egzersizleri, kontrast banyolar, transkutanöz elektriksel sinir stimülasyonu (TENS) gibi çeşitli yaklaşımlar uygulanır. ${ }^{[0,45]}$

\section{Osteoartrit}

Ortalama 6,7 yıl takip edilen eklem içi distal radius kırıklarının \%65'inde radyolojik olarak osteoartrit geliştiği, bu oranın radyokarpal eklemde düzensizlik ile iyileşenlerde \%91'ler, eklem hattı düzgün iyileşenlerde ise \%11'lerde görüldüğü bildirilmiştir. ${ }^{[22,46]}$ Genç hastalarda osteoartrit büyük problemdir. Tedavisinde aktivite ayarlamaları, oral analjezikler, atellemeler gibi konservatif yöntemler denenirken, bu gibi yöntemlerin başarısız olduğu durumlarda kısmi veya tam el bileği artrodezleri veya artroplastiler gündeme gelmektedir.

\section{Kaynamama veya geç kaynama}

Radyolojik incelemede, kırık hattını geçmesi gereken trabeküler yapının dört ay süre olmasına rağmen görülmemesine geç kaynama, altı ay olduktan sonra hala oluşmamasına da kaynamama denir. ${ }^{[25,47]}$ Kaynamama çok nadir görülen bir komplikasyondur. Açık kırıklar, ciddi parçalanma, enfeksiyon, kırık hattına yumuşak doku girmesi, kırık uçlarının kanlanmasını kaybetmesi ve patolojik durumlar kaynamama durumuna zemin hazırlar. ${ }^{[48]}$

\section{Yanlış kaynama}

Aktivitesi az yaşlı insanlarda çok önemli problemler yaratmasa da, genç ve aktif insanlarda eğri, ağrılı ve güçsüz bir el bileği sorun yaratır. Yanlış kaynayan radiusun en önemli deformitelerinden birisi kısalmış olarak kaynamasıdır (Şekil 16). Kısalarak iyileşen radiusta göreceli olarak ulna başı daha distalde kalır. Ulnar sıkışma sendromu da denilen ulna uzunluğu, karpal kemiklere yaptığı anormal baskıdan dolayı TFKK'de yıpranmaya ve ulnokarpal osteoartrite neden olur. Ulna ve radiustaki bu deformitelerden dolayı DRUE (distal radioulnar eklem) düzgünlüğü bozulur. Bu tablo, belirgin bir ulna başına, pronasyon-supinasyon kısıtlılığına ve ağrılı bir el bileğine yol açar. Distal radius yanlış kaynaması olan hastaya tedavi yaklaşımı belirli ilkeler dahilinde yapılır. Her hasta farklıdır ve radyolojik görüntülerden önce şikayetler, hastaların yaşam şekli, yaş ve fonksiyonel durumu değerlendirilmelidir. Tüm bu

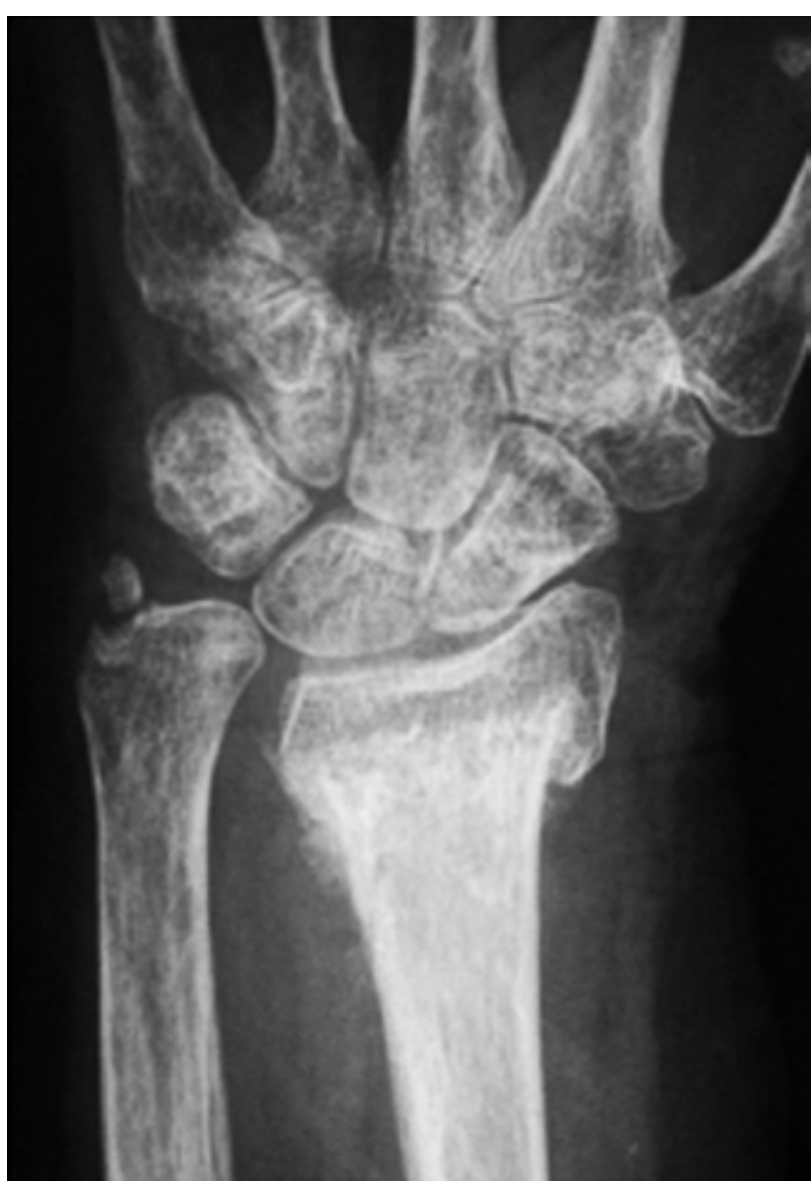

Şekil 16. Kısalarak kaynamış distal radius kırığı.

değişkenler değerlendirildikten sonra, tedavi şekli bunlara göre seçilir. Çok fazla şikayeti olmayan, çok aktif çalışmayan, nispeten çok genç olmayan hastalarda, radyolojik olarak ciddi yanlış kaynama görülmesine rağmen mutlak düzeltme endikasyonu yoktur. ${ }^{[49,50]}$

\section{Tendon komplikasyonları}

Tendonları etkileyen geç komplikasyonlar, kopmalar, tenosinovitler, yapışıklıklar ve tetik parmaktır. Yukarıda bahsedilen yaklaşım prensipleri geç dönemde de geçerlidir. ${ }^{[25]}$

\section{Dupuytren benzeri nodüller ve bantlar}

Kaymış distal radius kırığı olan 235 hastanın incelenmesinde \%11 olgunun travma sonrası 3-6. aylarda Dupuytren benzeri nodül ve bantların geliştiği gösterilmiştir. Gerçek Dupuytren'in aksine ilerleyici karekterde değildir ve hafif formdadır. ${ }^{[51]}$

\section{Sertlik}

Distal radius kırıkları sonrası el bileği EHA'nın kazanılması, hastaların normal günlük yaşam aktivitelerine 
dönmeleri için kaçınılmazdır. Kırık sonrası bir hareket kısıtlılığı gelişmişse, nedeni tespit edilmelidir. Daha sonra el bileğinin biyomekaniği ve anatomik özellikleri göz önünde bulundurulmalı, hastaya ait etmenler belirlenmeli ve rehabilitasyon süreci sonunda kazanılması beklenen gerçekçi hedefler sunulmalıdır.

El bileğinin normali, EHA fleksiyon-ekstansiyon yönünde $140^{\circ}$, pronasyon-supinasyon yönünde $150^{\circ}$ 'dir. Normal günlük yaşam aktivitesi için el bileği fleksiyon hareketinin $5-40^{\circ}$, ekstansiyon hareketinin $30-40^{\circ}$, ön kol pronasyon ve supinasyon hareketinin her iki yöne tek tek $50^{\circ}$ olmasının yeterli olduğu bildirilmiştir. ${ }^{[52-54]}$ Ancak, Chung ve arkadaşları, 2009'da yaptıkları hasta memnuniyeti ve fonksiyonel sonuçları karşılaştıran çalışmada, günlük yaşam aktivitelerinde hasta tatmini için, hastaların sağlam elleri ile karşılaştırıldığında kaba kavrama kuvvetinin \%65, lateral tutuş kuvvetinin \%85, el bileği hareket açıklığının ise $\% 95$ oranında iyileşmesi gerektiğini bildirmişlerdir. ${ }^{[55]}$ Literatürde, ekstansiyon ve ulnar deviyasyon kaybının, kaba kavrama kuvetinin zayıf olmasının fonksiyonel sonuçları negatif yönde etkilediği üzerinde durulmuştur. ${ }^{[56]}$

Distal radiusun anatomik ve biyomekanik özelliklerinin bozulması, sertliğin en başta gelen nedenlerinden birisidir. Dorsal açılanma, el bileğinde deformiteye yol açar ve ön kol dizilimini bozarak eklem hareket kısıtııı̆ıına yol açabilir. Hafif derecedeki dorsal açılanmalar bile midkarpal stabilitenin bozulmasına neden olabilir. Bu durum ise el bileği biyomekaniğinde tüm dengeleri bozabilir. Short ve arkadaşlarının yaptığı biyomekanik kadavra çalışmasında, distal radiusun $10^{\circ}$ 'lik normal palmar tilt açısının yanlış kaynama sonucu $45^{\circ}$ dorsale dönmesi ile ulnaya binen yükün \%21'den \%67'ye yükseldiği bildirilmiştir. ${ }^{[57]}$ Bu durum rehabilitasyon sürecinde, özellikle kuvvetlendirme egzersizlerinde hastaların ulnar taraf ağrısını açıklayabilir. ${ }^{[52]}$ Radiustaki hafif kısalık, el bileğinden geçen yük dağılımını bozarak, fleksiyon, ulnar deviyasyon ve pronasyon kaybına yol açabilir. Literatürde, $6 \mathrm{~mm}$ ve üzerindeki kısalıkların ön kol pronasyon-supinasyon kaybına neden olduğu bildirilmiştir. Radyolojik olarak 2 mm'den fazla radyal kısalık, $15^{\circ}$ yi aşan dorsal açılanma, $10^{\circ}$ 'yi aşan radyal açılanma kaybı tespit edilen olguların fonksiyonel sonuçlarının daha kötü olduğu bildirilmiştir. ${ }^{[56,58]}$

El bileğinin fleksiyon, ekstansiyon, radyal ve ulnar deviyasyon yanında ön kol supinasyon ve pronasyon hareketi de özellikle rehabilitasyon sürecinde göz önünde bulundurulmalıdır. Ön kol pronasyon-supinasyonu, üst ekstremitenin ve elin uzaysal düzlemde sınırsız hareketini sağlayan en önemli hareketlerinden biridir. Bu bölge travmalarından sonra DRUE'nin etkilenmesi, pronasyon-supinasyon kayıplarına neden olabilir.
Pronasyon-supinasyon kaybı, esas olarak distal radius dizilim bozukluğu, radyoulnar uzunluk farkı, eklem yüzey bozukluğu, kapsül veya kas gibi yumuşak doku kontraktürüne bağlı gelişiri. ${ }^{[59-61]}$

El bileğinde sertlik gelişmiş olan distal radius kırıklarında rehabilitasyon, erken dönemde midkarpal egzersizlerle başlamalıdır. Bu egzersizde, terapist başparmağı ile hastanın skafoid tüberkülüne bastırır; diğer eli ile bilek hareketi yaptırırken skafoidi stabilize ederek midkarpal hareketi sağlamaya çalışır (Şekil 17). EHA kazanılırken el bileği çevresindeki kas dengesinin sağlanması önem kazanmaktadır. Özellikle EKRB-L (ekstansör karpi radialis brevis-longus) ve FKU (fleksör karpi ulnaris) kaslarının kuwvetlenmesi, midkarpal hareketin geri kazanılmasında önemlidir. Bu iki kasın agonist-antagonist aktivitesi yanında EKU (ekstansör karpi ulnaris) ve FKR (fleksör karpi radialis) kasları da midkarpal eklemin rotasyon aksını kontrol eder. EKU ve FKR kaslarının kuwetlendirilmesi DTM (dart throwing motion)'nin tekrar sağlanmasına yardımcı olur. ${ }^{[62]}$

El bileği EHA'yı arttırmaya yönelik aktif, pasif egzersizlerle devam edilir. Pasif EHA egzersizleri ağrı sınırında uygulanmalıdır. Şiddetli ve ani germeler inflamasyonu tetikleyerek kısıtlılığın artmasına yol açabilir. Hastaya kendi vücut ağırlığı ve sonraki aşamalarda kum torbaları veya metal ağırlıklar ile gün içerisinde yapması gereken germe egzersizleri öğretilmelidir. Eklemde inflamatuvar bir süreç yoksa, germe egzersizleri öncesi dokularda ısı etkisi yaratmak için US uygulaması yapılabilir. Nemli sıcak yastıklar da (hotpack) kullanılabilen diğer sıcaklık ajanlarındandır. Bu şekilde derin ve yüzeyel sıcak uygulamaları ile yumuşak doku esnekliğinin arttırılması sağlanır. ${ }^{[63]}$

İnflamasyon olan olgularda soğuk uygulamalardan yararlanılır. EHA'yı geliştirmeye yönelik PNF (progressive neuromuscular facilitation) teknikleri uygulanır. EHA egzersizleri uygulanırken DRUE yer değiştirmesi üzerinde durulmalıdır. ${ }^{[59]}$ Ön kol rotasyon ve DRUE yer değiştirme egzersizleri, supinasyon kazanılmaya başlanınca uygulanır. Burada terapist dört parmağını ulna distaline, başparmağını ise volarda radius metafizine yerleştirir. Hasta aktif olarak supinasyon yaparken, dört parmak ulnayı volara, başparmak ise radiusu dorsale iter. Pronasyon sırasında ise tam tersi olarak, ulna dorsale, radius volara iter (Şekil 18).

Eklem hareket açıklılığını arttırmaya, kısalan yumuşak dokuları uzatmaya yönelik statik ilerleyici ateller de uygulanabilir. Bu ateller ile EHA'nın son noktasına kontrollü olarak ve uzun süreli direnç uygulanarak, kontrakte olmuş yumuşak dokuların uzaması sağlanır. ${ }^{[64,65]}$ 

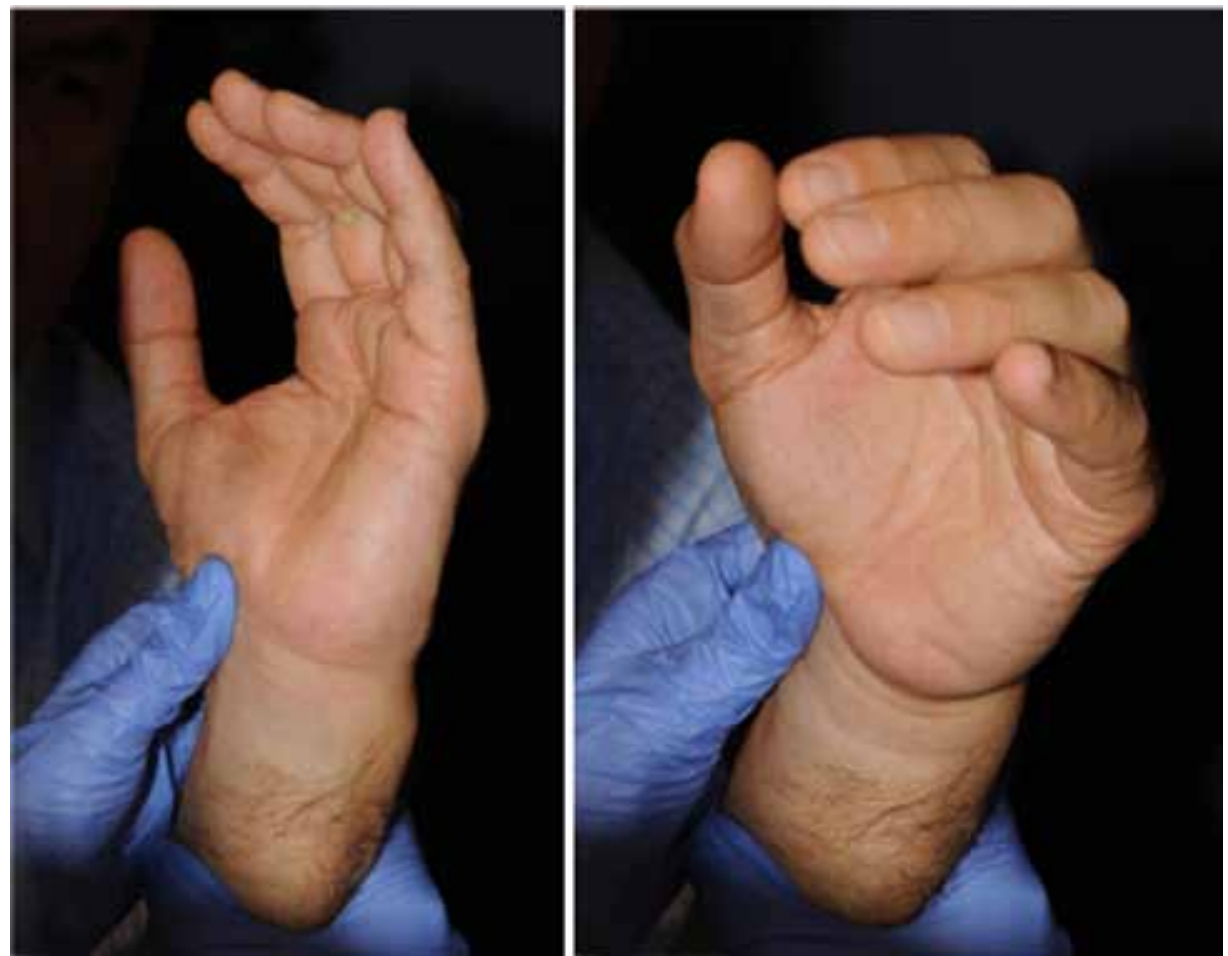

Şekil 17. Midkarpal egzersizler.

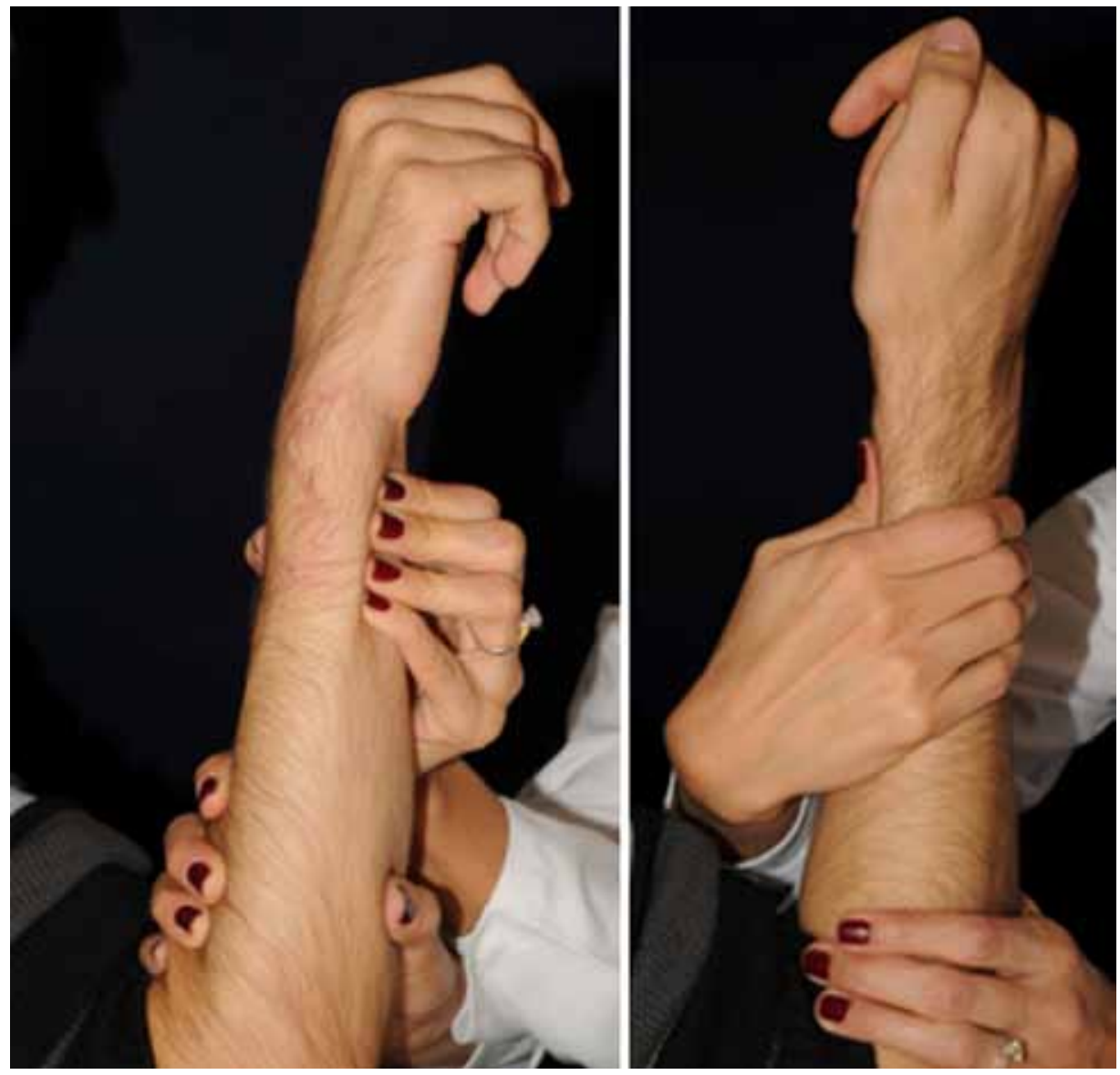

Şekil 18. Distal radyoulnar eklem yer değiştirme egzersizleri. 


\section{KAYNAKLAR}

1. Imrie $M$, Yao J. Distal radius fractures: A Historical perspective. In: Slutsky DJ, Osterman AL, editors. Fractures and Injuries of the Distal Radius and Carpus. Philadelphia: Saunders Elsevier, 2009. p.3-10.

2. Ilyas AM, Jupiter JB. Distal radius fractures--classification of treatment and indications for surgery. Hand Clin 2010;26(1):37-42. CrossRef

3. Herman M, Hopkins H, Slutsky DJ. Rehabilitation of distal radius fractures. In: Slutsky DJ, editor. Principles and Practice of Wrist Surgery. Philadelphia: Saunders Elsevier; 2010. p.166-82.

4. Slutsky DJ, Herman M. Rehabilitation of distal radius fractures: a biomechanical guide. Hand Clin 2005;21(3):455-68.

5. Fernandez DL. Closed manipulation and casting of distal radius fractures. Hand Clin 2005;21(3):307-16.

6. Wulf CA, Ackerman DB, Rizzo M. Contemporary evaluation and treatment of distal radius fractures. Hand Clin 2007;23(2):209-26.

7. Liporace FA, Adams MR, Capo JT, Koval KJ. Distal radius fractures. J Orthop Trauma 2009;23(10):739-48. CrossRef

8. Merrell GA, Truluck W. Nonoperative radius fractures. In: Slutsky DJ, editor. Principles and Practice of Wrist Surgery. Philadelphia: Saunders Elsevier; 2010. p.81-8.

9. Dias JJ. Nonoperative treatment of distal radius fractures. In: Slutsky DJ, Osterman AL, editors. Fractures and Injuries of the Distal Radius and Carpus. Philadelphia: Saunders Elsevier; 2009. p.11-15.

10. O'Connor D, Mullett H, Doyle M, Mofidi A, Kutty S, O'Sullivan M. Minimally displaced Colles' fractures: a prospective randomized trial of treatment with a wrist splint or a plaster cast. J Hand Surg Br 2003;28(1):50-3.

11. Prommersberger KJ, Pillukat T. Distal radius fractures. In: Ring DC, Cohen MS editors. Fractures of the Hand and Wrist. New York: Informa Healthcare USA, Inc.; 2007. p.137-87.

12. Kapoor H, Agarwal A, Dhaon BK. Displaced intra-articular fractures of distal radius: a comparative evaluation of results following closed reduction, external fixation and open reduction with internal fixation. Injury 2000;31(2):75-9.

13. Fernandez DL, Martin CJ. Classification and conservative treatment of distal radius fractures. In: Watson HK, Weinzweig J, editors. The Wrist. Philadelphia: Lippincott Williams \& Wilkins; 2001. p.277-98.

14. Earnshaw SA, Aladin A, Surendran S, Moran CG. Closed reduction of colles fractures: comparison of manual manipulation and finger-trap traction: a prospective, randomized study. J Bone Joint Surg Am 2002;84-A(3):354-8.

15. Gelberman RH, Szabo RM, Mortensen WW. Carpal tunnel pressures and wrist position in patients with Colles' fractures. J Trauma 1984;24(8):747-9.

16. Gupta A. The treatment of Colles' fracture. Immobilization with the wrist dorsiflexed. J Bone Joint Surg $\mathrm{Br}$ 1991;73(2):312-5.

17. Beumer A, McQueen MM. Fractures of the distal radius in low-demand elderly patients: closed reduction of no value in 53 of 60 wrists. Acta Orthop Scand 2003;74(1):98-100.

18. Moscony AMB. Common hand and wrist fractures. In: Cooper C, editor. Fundamentals of Hand Therapy. St. Louis, MO: Mosby Elsevier; 2007. p.251-83.

19. Trumble T, Glisson RR, Seaber AV, UrbaniakJR. Forearm force transmission after surgical treatment of distal radioulnar joint joint disorders. J Hand Surg Am 1987;12(2):196-202.
20. Putnam MD, Meyer NJ, Nelson EW, Gesenway D, Lewis JL. Distal radial metaphysial forces in an extrinsic grip model: implications for postfracture rehabilitation. J Hand Surg Am 2000;25(3):469-75.

21. McQueen MM, Hajducka C, Court-Brown CM. Redisplaced unstable fractures of the distal radius : a prospective randomised comparison of four methods of treatment. J Bone Joint Surg Br 1996;78(3):404-9.

22. Knirk JL, Jupiter JB. Intra-articular fracture of the distal end of the radius in young adults. J Bone Joint Surg Am 1986;68(5):647-59.

23. Chapmen DR, Bennett JB, Bryan WJ, Tullos HS. Complications of distal radial fractures: pins and plaster treatment. J Hand Surg Am 1982;7(5):509-12.

24. McKay SD, MacDermid JC, Roth JH, Richards RS. Assessment of complications of distal radius fractures and development of a complication checklist. J Hand Surg Am 2001;26(5):916-22.

25. Turner RG, Faber KJ, Athwal GS. Complications of distal radius fractures. Hand Clin 2010;26(1):85-96. CrossRef

26. Sanz J, Lizaur A, Sánchez Del Campo F. Postoperative changes of carpal canal pressure in carpal tunnel syndrome: a prospective study with follow-up of 1 year. J Hand Surg $\mathrm{Br}$ 2005;30(6):611-4.

27. Mack GR, McPherson SA, Lutz RB. Acute median neuropathy after wrist trauma. The role of emergent carpal tunnel release. Clin Orthop Relat Res 1994;(300):141-6.

28. Ford DJ, Ali MS. Acute carpal tunnel syndrome. Complications of delayed decompression. J Bone Joint Surg $\mathrm{Br}$ 1986;68(5):758-9.

29. Davis DI, Baratz M. Soft tissue complications of distal radius fractures. Hand Clin 2010;26(2):229-35. CrossRef

30. Stitik TP, Klecks R, Greenwald B. Özürlülük farmakoterapisi. In: De Lisa, editör. Fiziksel Tıp ve Rehabilitasyon: Illkeler ve Uygulamalar. Vol 2. Ankara-İstanbul: Güneş Kitabevleri; 2007. p.1205-51.

31. Larson RN. Desensitization and reeducation. In: Burke SL, Higgins J, McClinton MA, Saunders R, Valdata L, editors. Hand and Upper Extremity Rehabilitation: A Practical Guide. 3rd ed. New York: Churchill Livingstone; 2005. p.151-63.

32. McQueen MM, Gaston P, Court-Brown CM. Acute compartment syndrome. Who is at risk? J Bone Joint Surg $\mathrm{Br}$ 2000;82(2):200-3.

33. Simpson NS, Jupiter JB. Delayed onset of forearm compartment syndrome: a complication of distal radius fracture in young adults. J Orthop Trauma 1995;9(5):411-8.

34. Mackenney PJ, McQueen MM, Elton R. Prediction of instability in distal radial fractures. J Bone Joint Surg Am 2006;88(9):1944-51.

35. Trumble TE, Wagner W, Hanel DP, Vedder NB, Gilbert M. Intrafocal (Kapandji) pinning of distal radius fractures with and without external fixation. I Hand Surg Am 1998;23(3):381-94.

36. Gelb RI. Tendon transfer for rupture of the extensor pollisis longus. Hand Clin 1995;11(3):411-22.

37. Nunley JA, Rowan PR. Delayed rupture of the flexor pollisis longus tendon after inappropriate placement of the pi plate on the volar surface of the distal radius. J Hand Surg Am 1999;24(6):1279-80.

38. Bienek T, Kusz D, Cielinski L. Peripheral nerve compression neuropathy after fractures of the distal radius. J Hand Surg $\mathrm{Br}$ 2006;31(3):256-60. 
39. Mersky H, Bogduk N, editors. Classification of chronic pain: Descriptions of Chronic Pain Syndromes and Definitions of Pain Terms. Seattle, WA: IASP Press; 1994.

40. Chloros GD, Wiesler ER, Papadonikolakis A, Li Z, Smith $B P$, Koman LA. Complex regional pain syndrome after distal radius fractures. In: Slutsky DJ, Osterman AL, editors. Fractures and Injuries of the Distal Radius and Carpus. Philadelphia: Saunders Elsevier; 2009. p.247-57.

41. Atkins RM, Duckworth T, Kanis JA. Features of algodystrophy after Colles' fracture. J Bone Joint Surg Br 1990;72(1):105-10.

42. Bickerstaff DR, Kanis JA. Algodistrophy: an underrecognized complication of minor trauma. $\mathrm{Br} \mathrm{J}$ Rheumatol 1994;33(3):240-8.

43. Puchalski $P$, Zyluk A. Complex regional pain syndrome type 1 after fractures of the distal radius: a prospective study of the role of psychological factors. J Hand Surg $\mathrm{Br}$ 2005;30(6):574-80.

44. Astifidis RP. Pain related syndromes: Complex regional pain syndrome and fibromyalgia. In: Cooper C, editor. Fundamentals of Hand Therapy. St. Louis, MO: Mosby, Elsevier; 2007. p.376-87.

45. Li Z, Smith BP, Tuohy C, Smith TL, Koman LA. Complex regional pain syndrome after hand surgery. Hand Clin 2010;26(2):281-9. CrossRef

46. Bradway JK, Amadio PC, Cooney WP. Open reduction and internal fixation of displaced, comminuted intra-articular fractures of the distal end of the radius. J Bone Joint Surg Am 1989;71(6):839-47.

47. Fernandez DL, Ring D, Jupiter JB. Surgical management of delayed union and nonunion of distal radius fractures. J Hand Surg Am 2001;26(2):201-9.

48. Prommersberger KJ, Fernandez DL. Nonunion of distal radius fractures. Clin Orthop Relat Res 2004;(419):51-6.

49. Fernandez DL. Correction of post-traumatic wrist deformity in adults by osteotomy, bone-grafting, and internal fixation.J Bone Joint Surg Am 1982;64(8):1164-78.

50. Prommersberger KJ, Ring D, Gonzáles del Pino J, Capomassi M, Slullitel M, Jupiter JB. Corrective osteotomy for intraarticular malunion of the distal part of the radius. Surgical technique. J Bone Joint Surg Am 2006;88 Suppl 1 Pt 2:202-11.

51. Hove LM, Solheim E, Skjeie R, Sörensen FK. Prediction of secondary displacement of Colles' fracture. J Hand Surg Br 1994;19(6):731-6.

52. Laseter GF. Therapist's management of distal radius fractures. In: Mackin EJ, Callahan AD, Skirven TM, Schneider $\mathrm{LH}$, Osterman AL, editors. Rehabilitation of the Hand and Upper Extremity. 5th ed. St Louis: Mosby; 2002. p.1136-55.
53. Palmer AK, Werner FW, Murphy D, Glisson R. Functional wrist motion: a biomechanical study. J Hand Surg Am 1985;10(1):39-46.

54. Ryu JY, Cooney WP 3rd, Askew LJ, An KN, Chao EY. Functional ranges of motion of the wrist joint. J Hand Surg Am 1991;16(3):409-19.

55. Chung KC, Haas A. Relationship between patient satisfaction and objective functional outcome after surgical treatment for distal radius fractures. J Hand Ther 2009;22(4):302-7. CrossRef

56. Wilke MK, Abbaszagedan $\mathrm{H}$, Adolphson PY. Patient-percieved outcome after displaced distal radius fractures: A comparison between radiological parameters, objective physical variables, and the DASH score. J Hand Ther 2007;20(4):290-8.

57. Short WH, Palmer AK, Werner FW, Murphy DJ. A biomechanical study of distal radius fractures. J Hand Surg Am 1987;12(4):529-34.

58. Zemel NP. The prevention and the treatment of complications from fractures of the distal radius and ulna. Hand Clin 1987;3(1):1-11.

59. Kleinman WB. Distal radius instability and stiffness: common complications of distal radius fractures. Hand Clin 2010;26(2):245-64. CrossRef

60. Garcia-Elias M. Management of soft tissue contractures around the distal radioulnar joint. In: Slutsky DJ, editor. Principles and Practice of Wrist Surgery. Philadelphia: Saunders Elsevier; 2010. p.327-34.

61. Kleinman WB, GrahamTJ. The distal radioulnar joint capsule: clinical anatomy and role in posttraumatic limitation of forearm rotation. J Hand Surg Am 1998;23(4):588-99.

62. Hagert CG. Distal radius fracture and the distal radioulnar joint--anatomical considerations. Handchir Mikrochir Plast Chir 1994;26(1):22-6.

63. Moritomo $\mathrm{H}$. The kinematics and the clinical implications of the dart-throwing motion. In: Slutsky DJ, editor. Principles and Practice of Wrist Surgery. Philadelphia: Saunders Elsevier; 2010. p. $27-40$.

64. Michlovitz SL. Ultrasound and selected physical agent modalities in upper extremity rehabilitation. In: Mackin EJ, Callahan AD, Skirven TM, Schneider LH, Osterman AL, editors. Rehabilitation of the Hand and Upper Extremity. 5th ed. St Louis: Mosby; 2002. p.1745-62.

65. Flowers KR, LaStayo P. Effect of total end range time on improoving passive range of motion. J Hand Ther 1994;7(3):150-7. 